\title{
Aerosol optical characteristics and their vertical distributions under enhanced haze pollution events: effect of the regional transport of different aerosol types over eastern China
}

\author{
Tianze Sun ${ }^{1}$, Huizheng Che ${ }^{1}$, Bing $\mathrm{Qi}^{2}$, Yaqiang Wang ${ }^{1}$, Yunsheng Dong ${ }^{3}$, Xiangao $\mathrm{Xia}^{4,5}$, Hong Wang ${ }^{1}$, Ke Gui ${ }^{1}$, \\ Yu Zheng ${ }^{6}$, Hujia Zhao ${ }^{1}$, Qianli Ma ${ }^{7}$, Rongguang Du ${ }^{2}$, and Xiaoye Zhang ${ }^{1}$ \\ ${ }^{1}$ State Key Laboratory of Severe Weather (LASW) and Institute of Atmospheric Composition, \\ Chinese Academy of Meteorological Sciences, CMA, Beijing 100081, China \\ ${ }^{2}$ Hangzhou Meteorological Bureau, Hangzhou 310051, China \\ ${ }^{3}$ Key Laboratory of Environment Optics and Technology, Anhui Institute of Optics and Fine Mechanics, \\ Chinese Academy of Science, Hefei 230031, China \\ ${ }^{4}$ Laboratory for Middle Atmosphere and Global Environment Observation (LAGEO), Institute of Atmospheric Physics, \\ Chinese Academy of Sciences, Beijing 100029, China \\ ${ }^{5}$ School of Geoscience University of Chinese Academy of Science, Beijing 100049, China \\ ${ }^{6}$ Collaborative Innovation Center on Forecast and Evaluation of Meteorological Disasters, \\ Nanjing University of Information Science \& Technology, Nanjing 210044, China \\ ${ }^{7}$ Lin'an Regional Air Background Station, Lin'an 311307, China
}

Correspondence: Huizheng Che (chehz@camscma.cn) and Xiangao Xia (xxa@mail.iap.ac.cn)

Received: 29 August 2017 - Discussion started: 20 September 2017

Revised: 9 January 2018 - Accepted: 15 January 2018 - Published: 1 March 2018

\begin{abstract}
The climatological variation of aerosol properties and the planetary boundary layer (PBL) during 2013-2015 over the Yangtze River Delta (YRD) region were investigated by employing ground-based Micro Pulse Lidar (MPL) and CE-318 sun-photometer observations. Combining Moderate Resolution Imaging Spectroradiometer (MODIS) and Cloud-Aerosol Lidar and Infrared Pathfinder Satellite Observation (CALIPSO) satellite products, enhanced haze pollution events affected by different types of aerosol over the YRD region were analyzed through vertical structures, spatial distributions, backward trajectories, and the potential source contribution function (PSCF) model. The results show that aerosols in the YRD are dominated by fine-mode particles, except in March. The aerosol optical depth (AOD) in June and September is higher due to high single scattering albedo (SSA) from hygroscopic growth, but it is lower in July and August due to wet deposition from precipitation. The PBL height $(\mathrm{PBLH})$ is greater (means ranging from 1.23 to $1.84 \mathrm{~km}$ ) and more variable in the warmer months of March to August, due to the stronger diurnal cycle and exchange of heat. Northern fine-mode pollutants are brought to
\end{abstract}

the YRD at a height of $1.5 \mathrm{~km}$. The SSA increases, blocking the radiation to the surface, and cooling the surface, thereby weakening turbulence, lowering the PBL, and in turn accelerating the accumulation of pollutants, creating a feedback to the cooling effect. Originated from the deserts in Xinjiang and Inner Mongolia, long-range transported dust masses are seen at heights of about $2 \mathrm{~km}$ over the YRD region with an $\mathrm{SSA}_{440 \mathrm{~nm}}$ below 0.84, which heat air and raise the PBL, accelerating the diffusion of dust particles. Regional transport from biomass-burning spots to the south of the YRD region bring mixed aerosol particles at a height below $1.5 \mathrm{~km}$, resulting in an $\mathrm{SSA}_{440 \mathrm{~nm}}$ below 0.89. During the winter, the accumulation of the local emission layer is facilitated by stable weather conditions, staying within the PBL even below $0.5 \mathrm{~km}$. 


\section{Introduction}

Aerosol particles influence Earth's radiation budget and play a significant role in global and regional climate change (Hansen et al., 1997; Che et al., 2015a; Zhang et al., 1998; Li et al., 2016). Despite numerous studies on aerosols, there is still much uncertainty surrounding aerosol optical properties in relation to current assessments and predictions of global climatic change (IPCC, 2007; Stocker et al., 2013). The frequent occurrence of regional pollution demands worldwide attention because of the serious consequences it can have on visibility and human health (Wu et al., 2012; Sun et al., 2018; Chan and Yao, 2008; Bi et al., 2015).

The planetary boundary layer (PBL) is a critical component of Earth's climate system (Medeiros et al., 2005). The PBL is directly coupled with the land surface, and its height (PBLH) plays a significant role in determining the vertical distributions of aerosol particles (Deardorff, 1972). Based on the research of Tang et al. (2016), the atmospheric mixing layer provides useful empirical information for improving meteorological and atmospheric chemistry models and the forecasting and warning of air pollution. The higher the accumulation of ambient aerosols, the less solar radiation reaches the surface, which will further restrict the development of the PBL, thus compounding the air pollution near the surface during prolonged stagnant weather conditions (Gao et al., 2015; Petäjä et al., 2016; Leng et al., 2015). Lidar measures the intensity of backscattered light as a function of distance from the instrument. The change in backscatter across the top of the boundary layer provides a convenient means of determining the PBLH. Long-term, continuous PBLHs are provided by Micro Pulse Lidar (MPL) observations to ascertain seasonal variations (Ku et al., 2006; Lewis et al., 2013).

To analyze the spatiotemporal distribution of aerosol optical properties, multiple measurements from diverse angles have been conducted by researchers worldwide. Satellite remote sensing and ground-based observations are two approved ways of monitoring the long-term variation of Earth's aerosol properties. Holben et al. (2001), Che et al. (2015a), and Tao et al. (2014) used ground-based Cimel sunphotometers and found a decreasing trend in aerosol optical depth (AOD) from 2006 to 2009, but an increase of $\sim 0.03$ from 2009 to 2013 in China. Chauvigné et al. (2016) compared aerosol extinction with continuous high-altitude nearsurface in situ measurements and low-altitude ground-based remote sensing atmospheric column measurements over a 1year period at the Puy de Dôme station, utilizing several in situ instruments such as the Cimel sun-photometer for the whole column, and lidar for vertical multi-altitude. $\mathrm{Wu}$ et al. (2017) used a variety of ground-based instruments and satellite sensors, including Moderate Resolution Imaging Spectroradiometer (MODIS), Atmospheric Infrared Sounder (AIRS), Cloud-Aerosol Lidar and Infrared Pathfinder Satellite Observation (CALIPSO), and Ozone Monitoring Instrument (OMI) products, to detail an integrated observation of an agricultural biomass-burning episode in Nanjing, China. It is significant to estimate the leading pollution contributor using a combination of remote sensing and satellite data (Z. Chen et al., 2017). Along with the observations, trajectory models (e.g., HYSPLIT) for air mass tracking and potential source apportionment have been applied to analyze the origins of aerosols (Wang et al., 2006b).

The Yangtze River Delta (YRD) region is a key economic and cultural hub in China, with progressive development resulting in further particle emissions from industry and other anthropogenic activities. Many studies have been conducted on the aerosol optical properties and their variations in the cities of the YRD, such as Shanghai, Nanjing, Lin'an, and Taihu (Xia et al., 2007; Pan et al., 2010; He et al., 2012; Ding et al., 2013; Liu et al., 2015; Xing et al., 2017). Particularly in Hangzhou, the capital city of Zhejiang province, some researchers have focused on determining the seasonal variation of aerosol properties, chemical compositions, and particulate matter (PM) concentrations (Qi, 2016; Ming et al., 2017; Xiao et al., 2011), or single-case analyses on features of a particular pollution process (Chen et al., 2012; Fu et al., 2014; Li et al., 2015). However, research into the sources of pollutants in the YRD region is still needed to understand the mechanisms underlying haze pollution. Among these studies, there is a lack of long-term analysis of aerosols and their sources. In addition, single-case analysis is insufficiently representative of a site that experiences frequent haze occurrence. There are a lack of comprehensive studies in progress that analyze multiple aspects. In particular, studies in the YRD urban area have been based almost exclusively on data from in situ measurements, or on whole-column measurements that do not resolve the vertical distribution. This can be obtained from satellite monitoring or ground-based lidar measurements. The retrieved time-height cross section of the extinction coefficient can reflect the vertical distribution and structure of the aerosol layer continuously, which will contribute to the optimization of the satellite retrieval algorithm and the verification and improvement of the results from both satellites and models.

In this study, multiple data sources are analyzed to further understand the mechanisms underlying haze pollution affected by different aerosol transportation over the YRD region in eastern China. Hangzhou is selected as a representative site. The remainder of the paper is organized as follows: in Sect. 2, the methods and data are presented, and in Sect. 3, seasonal aerosol optical properties, PM concentrations, and PBLHs from 2013 to 2015 are analyzed to illustrate the general aerosol characteristics over the urban area of the YRD. Four typical haze pollution episodes affected by different types of aerosol transported to the urban area of the YRD are analyzed using ground-based sun-photometer and MPL data for obtaining the optical properties and vertical distribution, satellite data from MODIS and CALIPSO for confirming the observed results, PM concentration data to build an overview of the spatial distribution of pollutants in eastern China, and 


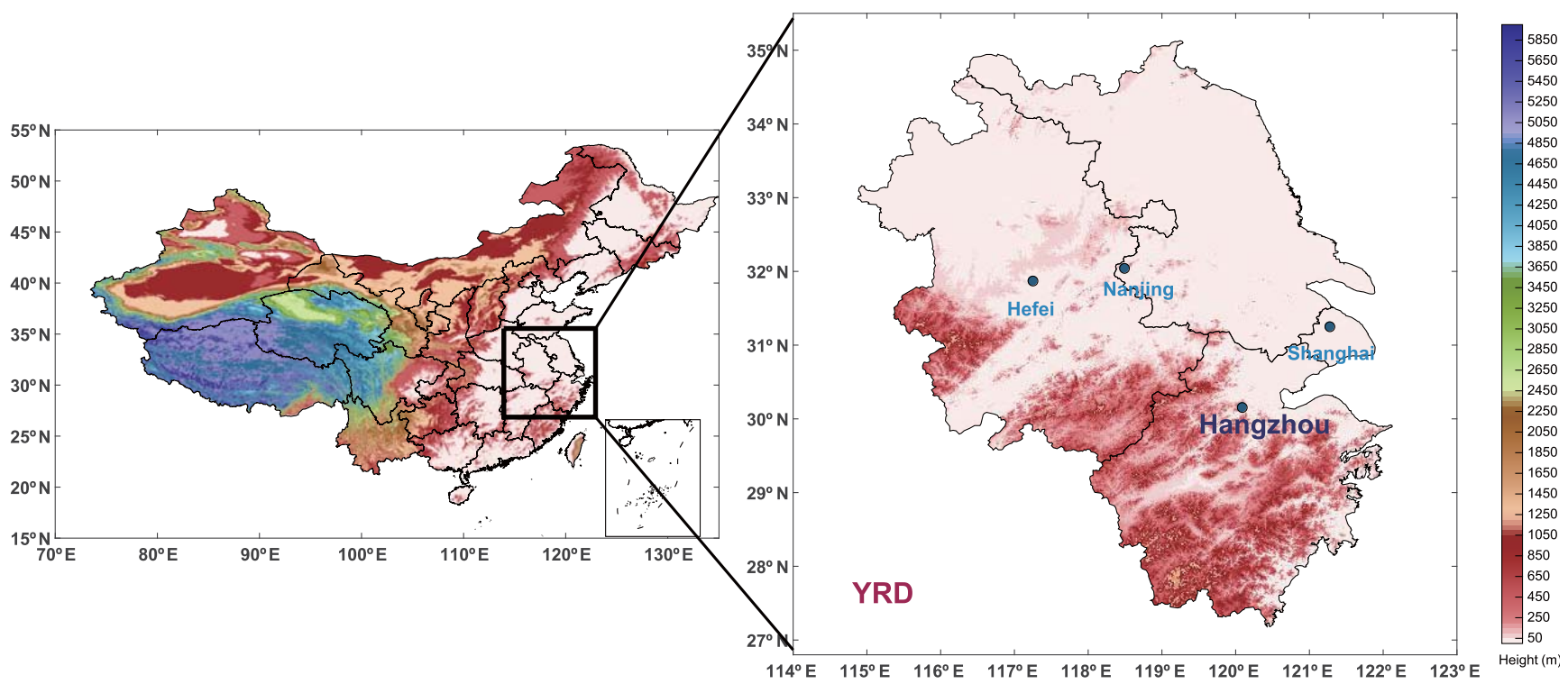

Figure 1. Terrain elevation and location of the Yangtze River Delta region in China.

reanalysis data for depicting the wind fields and calculating backward trajectories and potential source contributions. In Sect. 4 , a brief summary is given.

\section{Methods and data}

\subsection{Ground-based sun-photometer and lidar measurements}

In this study, the aerosol optical properties were measured in Hangzhou $\left(30^{\circ} 14^{\prime} \mathrm{N}, 120^{\circ} 10^{\prime} \mathrm{E}\right.$; $41.7 \mathrm{~m}$ a.s.l.). This site lies in the West Lake scenic area, which is a commercial and residential area in the southern part of the city (Fig. 1). The AOD at 440, 670, 870, and $1020 \mathrm{~nm}$ was measured from January 2013 to December 2015 using a CE-318 sun-photometer with a $1.2^{\circ}$ full field of view (Holben et al., 1998). The validated AOD data presented in this article were obtained using the ASTPwin software developed by Cimel Co. Ltd. (Che et al., 2013) for level 1.5 AOD (cloud-screened). Aerosol optical properties were processed using the method of Dubovik et al. (2000) and Dubovik and King (2000), based on the almucantar measurement data of the Cimel sun-photometer. The Cimel sky radiance measurements taken at 440, 670, 870 , and $1020 \mathrm{~nm}$, in conjunction with direct sun AOD data collected at the same wavelengths, were used to retrieve volume aerosol size distributions $(\mathrm{d} V / \mathrm{d} \ln (r)$ in the size range 0.05 to $15 \mu \mathrm{m}$ ), single scattering albedo (SSA) values, Ångström exponent (AE), absorption AOD (AAOD), and volume concentrations of fine- and coarse-mode aerosols (Eck et al., 2010; Che et al., 2014). Only SSA and AAOD results with $\mathrm{AOD}_{440 \mathrm{~nm}}>0.40$ were used due to the high uncertainties inherent in lower AOD values (Che et al., 2015b).
The ground-based lidar instrument used was the MPL in stalled at the Hangzhou National Reference Climatology Station. The MPL produced by Sigma Space Corporation is an elastic back-scattering lidar, equipped with a $532 \mathrm{~nm}$ wavelength laser launcher. In this study, aerosol measurements were obtained with a $30 \mathrm{~m}$ range resolution and a $30 \mathrm{~s}$ accumulation time, and a blind area of detection existed ranging from 200 to $300 \mathrm{~m}$. The aerosol extinction coefficient profiles, PBLH, and AOD were retrieved during 2013-2015 using the algorithm of Fernald (1984), which considers the atmosphere to be comprised of aerosols and air molecules (Liu et al., 2016).

\subsection{MODIS and CALIPSO data}

The MODIS instrument operates on both the Terra and Aqua satellites. In this study, to illustrate the spatial distribution of AOD, we used the daily AOD combined dark target and deep blue data at $550 \mathrm{~nm}$ for land and ocean from MODIS Level 2 Atmosphere Products, during 9-15 October 2015 (Levy et al., 2007a, b). Global MODIS hotspots detected during 6-13 August 2013 in China were obtained from the Fire Information for Resource Management System for fire locations (https://firms.modaps.eosdis.nasa.gov/).

The products of CALIPSO were used for this study, and these are available at the NASA Langley Research Center (https://www-calipso.larc.nasa.gov/). The primary instrument carried on the CALIPSO satellite is the Cloud-Aerosol Lidar with Orthogonal Polarization (CALIOP). In this work, we selected the V4.10 CALIOP Level 2 data products to acquire the images of vertical feature masks and aerosol subtypes (Omar et al., 2009; Winker et al., 2009; Vaughan et al., 2004). 


\subsection{Reanalysis data for the PBLH and wind field}

The reanalysis data for the PBLH and wind fields were downloaded from the European Centre for Medium-Range Weather Forecasts (ECMWF), ERA-Interim (http://apps. ecmwf.int/datasets/). The monthly average PBLH values were from 2013 to 2015, and the daily wind fields were analyzed at different pressure levels with a spatial resolution of $0.5^{\circ} \times 0.5^{\circ}$.

\subsection{Surface in situ $\mathrm{PM}_{2.5}$ and $\mathrm{PM}_{10}$ data}

In 2012, the China National Environmental Monitoring Center began to make hourly observations of $\mathrm{PM}_{2.5}, \mathrm{PM}_{10}$, and other atmospheric pollutants in 367 major cities in China (http://106.37.208.233:20035/). In this work, the hourly data were processed to obtain the daily and monthly $\mathrm{PM}_{2.5}$ and $\mathrm{PM}_{10}$ concentration results during 2013-2015.

\subsection{Backward trajectory, PSCF, and CWT analysis}

Three-dimensional $72 \mathrm{~h}$ air mass backward trajectories at multiple altitudes over Hangzhou every $6 \mathrm{~h}$ (00:00, 06:00, 12:00, and 18:00 UTC) were calculated using the NCEP FNL (National Centers for Environmental Prediction Final Analyses) archive data. The software TrajStat (http://www. meteothinker.com/products/trajstat.html) (Ngan et al., 2015) was used. The cluster methods of air mass backward trajectories from Sirois and Bottenheim (1995) were applied to confirm the major transport pathways.

To determine the pollutants' source locations and prevailing transport pathways, backward trajectories combined with $\mathrm{PM}$ concentrations (referred to as the potential source contribution function (PSCF) model and concentration weighted trajectory (CWT) model) were used. A weighting function was applied to better reflect the uncertainty in the values, and this is referred to as WPSCF and WCWT in each model, respectively (Polissar et al., 1999; Hsu et al., 2003; Xin, 2016; Seibert et al., 1994). The specifics of the two models' parameters and algorithms have been described in detail by Wang et al. (2006b).

\section{Results and discussion}

\subsection{Variation in $\mathbf{P M}_{2.5}$ and $\mathbf{P M}_{10}$ mass concentration}

Figure $2 \mathrm{a}$ shows the monthly variation in mass concentrations of $\mathrm{PM}_{2.5}$ and $\mathrm{PM}_{10}$ and the proportion of $\mathrm{PM}_{2.5}$ to $\mathrm{PM}_{10}$ during 2013-2015 in Hangzhou. It can be seen that mass concentrations of $\mathrm{PM}_{10}$ and $\mathrm{PM}_{2.5}$ in the YRD region are distinctly higher in January $\left(129.39 \mu \mathrm{g} \mathrm{m}^{-3}\right)$, November $\left(96.32 \mu \mathrm{g} \mathrm{m}^{-3}\right)$, and December $\left(119.16 \mu \mathrm{g} \mathrm{m}^{-3}\right)$ than in other months, while the $\mathrm{PM}_{2.5}: \mathrm{PM}_{10}$ ratio during these months plus February also exceeds other months, ranging from 76.1 to $86.6 \%$. Meanwhile, the lowest concentrations occur in
July and August, which can result from wet deposition due to the abundant precipitation at this time of year (Jacob and Winner, 2009). These results verify the findings of Ming et al. (2017), Cao et al. (2009), and Wang et al. (2006a), that the highest and lowest $\mathrm{PM}_{2.5}$ mass concentrations occur, respectively, during the winter and summer in the YRD region. For the other months, concentrations of $\mathrm{PM}_{10}$ are high but the $\mathrm{PM}_{2.5}$ accounts for less than $65 \%$ during March to May.

\subsection{Variation in aerosol optical properties}

Figure $2 \mathrm{~b}$ depicts the monthly means of the AE between 440 and $870 \mathrm{~nm}$ and the AOD at four different wavelengths (440, 670, 870, and $1020 \mathrm{~nm}$ ) in Hangzhou during 2013-2015, retrieved from the CE-318 sun-photometer. The monthly variation trends of AOD means at the four wavelengths are consistent, and the values of $\mathrm{AOD}_{440 \mathrm{~nm}}$ are the highest among them. The averaged $\mathrm{AOD}_{440 \mathrm{~nm}}$ values during January to May are about 0.8 , and the AOD values at the four wavelengths reach their maxima in June at $1.20 \pm 0.55,0.76 \pm 0.37$, $0.54 \pm 0.25$, and $0.43 \pm 0.20$, respectively. After June, AODs reduce to less than 0.8 , and in August the mean values reach their minima at $0.59 \pm 0.34,0.32 \pm 0.21,0.23 \pm 0.14$, and $0.18 \pm 0.10$, respectively. In September, the values increase again to $1.07 \pm 0.54,0.63 \pm 0.38,0.43 \pm 0.26$, and $0.32 \pm 0.20$, respectively, after which the $\mathrm{AOD}_{440 \mathrm{~nm}}$ means decrease below 0.8 during October to December.

In general, AODs in June and September are relatively high; yet in July and August they are lower than in other months. The results of July and August agree with Qi (2016) that the lowest AOD appears in summer, with a mean value of $0.72 \pm 0.58$ at $440 \mathrm{~nm}$ in Hangzhou. According to Che et al. (2014), the relatively low PM mass concentrations may result from the substantially increased precipitation in the YRD region in summer (including July and August) due to the summer monsoon, which can decrease the concentration of atmospheric aerosols through wet deposition. This pattern has also been observed in Taihu and Lin'an (Pan et al., 2010). Because the subtropical anticyclone begins to move north and precipitation decreases from the end of August to the beginning of September, the AOD increases in September. Nevertheless, the peak in the monthly AOD means in Pudong occurs in June, which may derive from the stable weather caused by the lack of strong winds (Duan and Mao, 2007).

The monthly mean AEs ( $\mathrm{AE}_{440-870 \mathrm{~nm}}$ ) vary almost inversely to the AOD and are all greater than 0.8 , which indicates that the AODs are dominated by fine particles in the YRD region during 2013-2015 (Qi, 2016; Eck et al.,

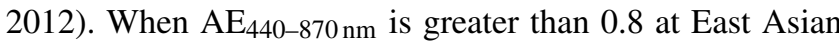
sites, fine-mode aerosols emitted from population centers in East Asia dominate the aerosol optical properties even on spring dust days, during which pollution aerosols are mixed with coarse-mode particles. Comparing the bars' heights in the figure, the minimum monthly averaged $\mathrm{AE}_{440-870 \mathrm{~nm}} \mathrm{Oc}-$ 

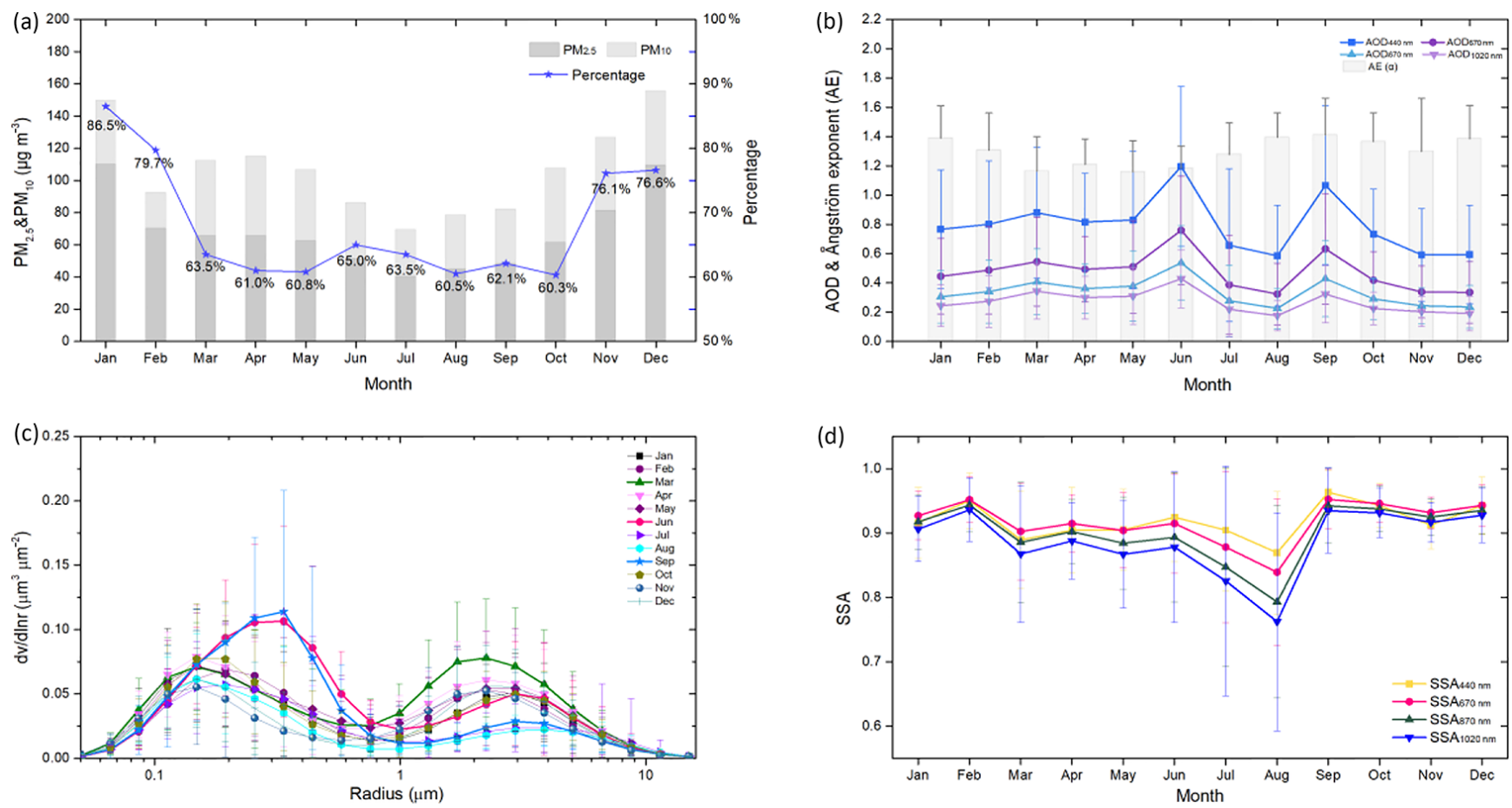

Figure 2. Monthly variation in averaged (a) mass concentration of $\mathrm{PM}_{2.5}$ and $\mathrm{PM}_{10}$, (b) $\mathrm{AOD}(440,670,870$, and $1020 \mathrm{~nm})$ and $\mathrm{AE}$ (between 440 and $870 \mathrm{~nm}$ ), (c) volume size distribution, and (d) SSA (440, 670, 870, and $1020 \mathrm{~nm}$ ), during 2013-2015 in Hangzhou.

curs in March $(1.16 \pm 0.24)$ and the maximum in September $(1.41 \pm 0.25)$. This shows the influence of long-distance dust transport from the desert districts located in northern and northwestern China (Zhang and Li, 2012; Gong et al., 2003), which can have an influence on the YRD region.

Figure $2 \mathrm{c}$ shows the monthly volume size distributions of aerosols during 2013-2015 in Hangzhou. In general, the size distributions show a bimodal logarithm normal structure: a fine mode with radius $<0.6 \mu \mathrm{m}$ and coarse mode with radius $>0.6 \mu \mathrm{m}$ (Dubovik et al., 2002). Nevertheless, in June and September, the distribution appears trimodal, indicating a tendency for hygroscopic growth in fine-mode particles in the YRD region (Pilat and Charlson, 1966). In June and September, the fine modes reach maximum peaks at a radius of $0.34 \mu \mathrm{m}$, while other months' peaks occur at a radius of $0.15 \mu \mathrm{m}$. As for the coarse mode, March, April, November, and December peaks occur at a radius of $2.24 \mu \mathrm{m}$, while the peak radius during the other months is larger than $2.24 \mu \mathrm{m}$. Because of the dust transport, coarse modes dominate in March, while in July, August, and September the coarse mode only contributes a small fraction. Conversely, the fine particles play a leading role in the other months, particularly in June and September. This situation may arise due to the mixed influence of hygroscopic growth, coagulation growth, and different species of aerosols emitted from various sources ( $\mathrm{Li}$ et al., 2007; Zhu et al., 2014; Che et al., 2014). Hygroscopic properties of ambient particles in urban Hangzhou are mainly a function of their size and chemical composition (Zhang et al., 2011). Since the highest AOD values are seen in June (but not in July and August), it is suggested that the hygroscopic growth in the fine mode leads to enhanced scattering, which significantly raises the AOD values in the YRD region.

The SSA is defined as the ratio of the scattering coefficient to the extinction coefficient, and it is one of the key parameters used in assessing the radiation effect on climate change (Jacobson, 2000). Highly absorbing particles, including urban industrial aerosols, have a warming effect, while low absorbing particles such as dust can have a cooling effect (Dubovik et al., 2002). Figure 2d shows the monthly variation of SSA at the $440,670,870$, and $1020 \mathrm{~nm}$ wavelengths. From September to February, the SSAs at the four wavelengths are close and relatively high. However, over the warmer months of March to August, the values decrease and the difference between the wavelengths becomes greater, particularly in July and August with low SSA, which may imply that the low-SSA particles are more sensitive to the wavelength variability. The minimum SSAs occur in August at $0.869 \pm 0.095,0.839 \pm 0.114,0.793 \pm 0.149$, and $0.762 \pm 0.169$, respectively; the maximum is in September, with the highest value of $0.963 \pm 0.033$ at $440 \mathrm{~nm}$. As a result, the aerosols in the YRD region during August tend to be absorbing, but during September the hygroscopic aerosol particles become more capable of light scattering through condensation and evaporation of water vapor (Adachi et al., 2015), which may result from the variability of the aerosols' 
composition and sources in the ambient atmosphere. According to studies by Qi (2016) and Xia et al. (2007), the absence of a heating period in southern China in winter causes higher SSA than in northern cities such as Beijing, where biomass burning can emit black and organic carbon. According to the results of monthly AOD and the volume size distribution presented in this article, the high level of AOD in September may be due to the strong scattering ability provided by the prominent hygroscopic growth.

\subsection{Variation in the PBLH measured by lidar}

In this study, by utilizing the backscatter signal at $532 \mathrm{~nm}$ with an MPL, the PBLHs from 2013 to 2015 at Hangzhou were retrieved at a $10 \mathrm{~min}$ temporal and $30 \mathrm{~m}$ spatial resolution. To verify the reliability of these PBLHs, we used the monthly averaged reanalysis data of the PBL from ERAInterim to obtain a linear fit with the PBLHs from MPL (after computing the monthly average). The Pearson's correlation coefficient between these two monthly averaged series is 0.88 , which passes the significance test at the $p=0.1$ level. Despite the strong correlation between the reanalysis- and the MPL-derived PBLH, the values obtained from the reanalysis data are significantly lower than those from the MPL. It is suggested that improvements are needed in the reanalysis data.

Since the PBLHs retrieved from the MPL are reliable, we adopt them to examine the monthly variation characteristics in the YRD region during 2013-2015. Figure 3 shows the monthly averaged height of the PBL and its 5th and 95th percentile box plots during 2013-2015 in Hangzhou. Due to the blind detection area of the MPL, the minimum value is about $300 \mathrm{~m}$ above the surface. During the warmer months (including March to August), the monthly means of the PBLH are above $1 \mathrm{~km}$, and the range between the 5th and 95th percentiles is greater than $1 \mathrm{~km}$, varying from above $0.5 \mathrm{~km}$ to about $2 \mathrm{~km}$. Conversely, mean PBLHs in the colder months are almost below $1 \mathrm{~km}$ and the range between the 5 th and 95th percentiles is half that in the warmer months, ranging from about $0.5 \mathrm{~km}$ to below $1.5 \mathrm{~km}$. The wider range in the warmer months may result from a stronger diurnal cycle (Liu and Liang, 2010) and daily exchange of heat and mass in the PBL (Medeiros et al., 2005). These characteristics help to explain the higher in situ PM mass concentrations in the winter months than in summer discussed above.

\subsection{Case analysis of pollution sources}

For a further explanation of the monthly variation in aerosol optical properties, and to examine the variety of pollutant sources affecting the enhanced haze pollution events in the YRD region, four cases with different transportation categories are discussed here, combining ground-based observation, remote sensing, reanalysis, and satellite data, to build a comprehensive analysis (Fig. S6 in the Supplement).

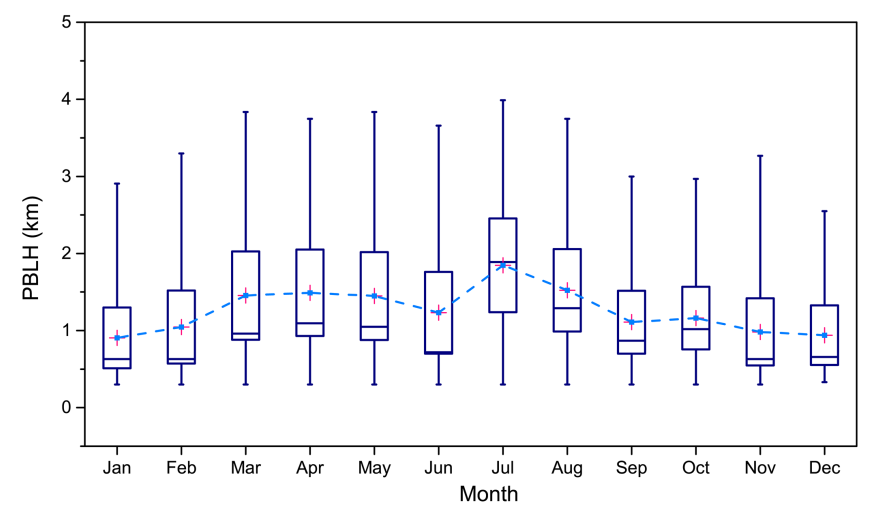

Figure 3. Monthly variation of averaged PBLH retrieved from the MPL, and their 5th and 95th percentile box plots during 2013-2015 in Hangzhou.

\subsubsection{Pollutants transported from polluted areas in northern China}

A few episodes of pollutants transported from northern China were detected by the MPL, as illustrated in Fig. 4a, which shows the time-height cross section of extinction coefficients in Hangzhou. The aerosol vertical distributions were further assessed by extracting profiles of aerosol extinction coefficient from the MPL on a daily basis during this period (Fig. 5). On the first day, 9 October 2015, the thin external aerosol layer is seen around $1 \mathrm{~km}$ during nighttime, when the maximum extinction coefficient is more than $0.6 \mathrm{~km}^{-1}$, and this is separate from the lower local pollutants layer. During the following three days, the external aerosol masses are around $1 \mathrm{~km}$ at nighttime and above $1.5 \mathrm{~km}$ during the daytime, and they appear to be multilayer in structure. Meanwhile, the daily averaged PBLH is around 1.2 and $1.5 \mathrm{~km}$ on 11 October and 12 October, respectively, sitting above the aerosol layer at nighttime and beneath it during the day (Fig. 6). With the PBL pushing down, the aerosol layer begins to descend from the afternoon of 12 October, continues to descend to below $1 \mathrm{~km}$ until 15 October, and then mixes downwards into the local emissions aerosol layer. Concurrently, the peak extinction coefficients vary from 0.2 to $0.5 \mathrm{~km}^{-1}$, reaching their maxima when the external and local pollutants mix together in the PBL. To verify the significance of the PBL in this process, the Pearson's correlation coefficient between the daily averaged PBLH from the MPL and the daily mass concentration of $\mathrm{PM}_{2.5}$ during 9-15 October was computed. The result appears negative, at -0.88 (passing the significance test at the $p=0.1$ level), which indicates that the descending PBL accelerates the accumulation of PM mass from the two aerosol layers in it.

Aerosol optical properties from the CE-318 retrieval data are exhibited in Fig. 6. According to the pattern of volume size distribution during 11-15 October 2015, the fine mode dominates, which can be related to the volume of both modes 

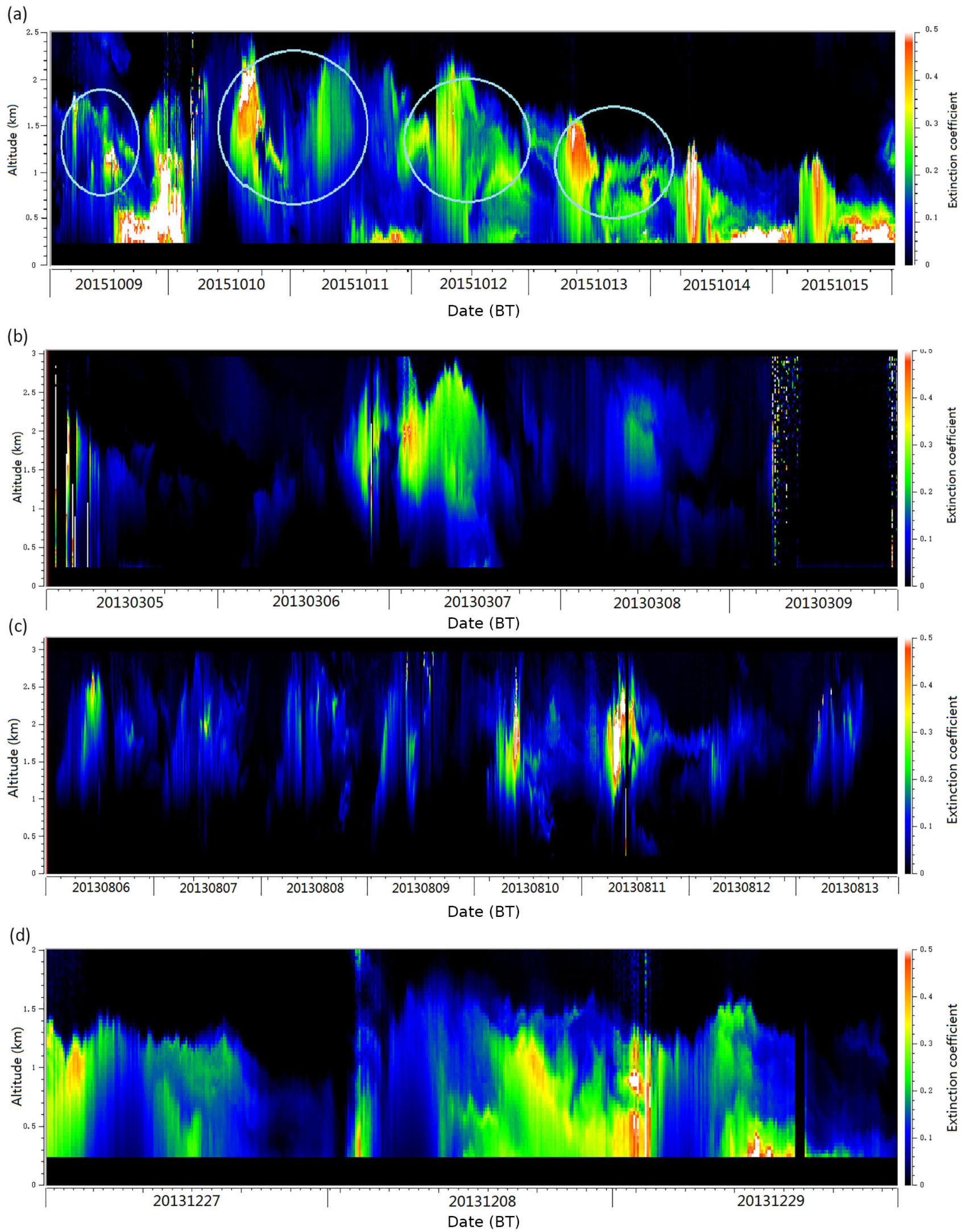

Figure 4. Time-height cross section of the ground-based lidar-derived extinction coefficient at $532 \mathrm{~nm}$ in Hangzhou during (a) 9-15 October 2015, (b) 5-9 March 2013, (c) 6-13 August 2013, and (d) 27-29 December 2013. BT refers to Beijing Time. 

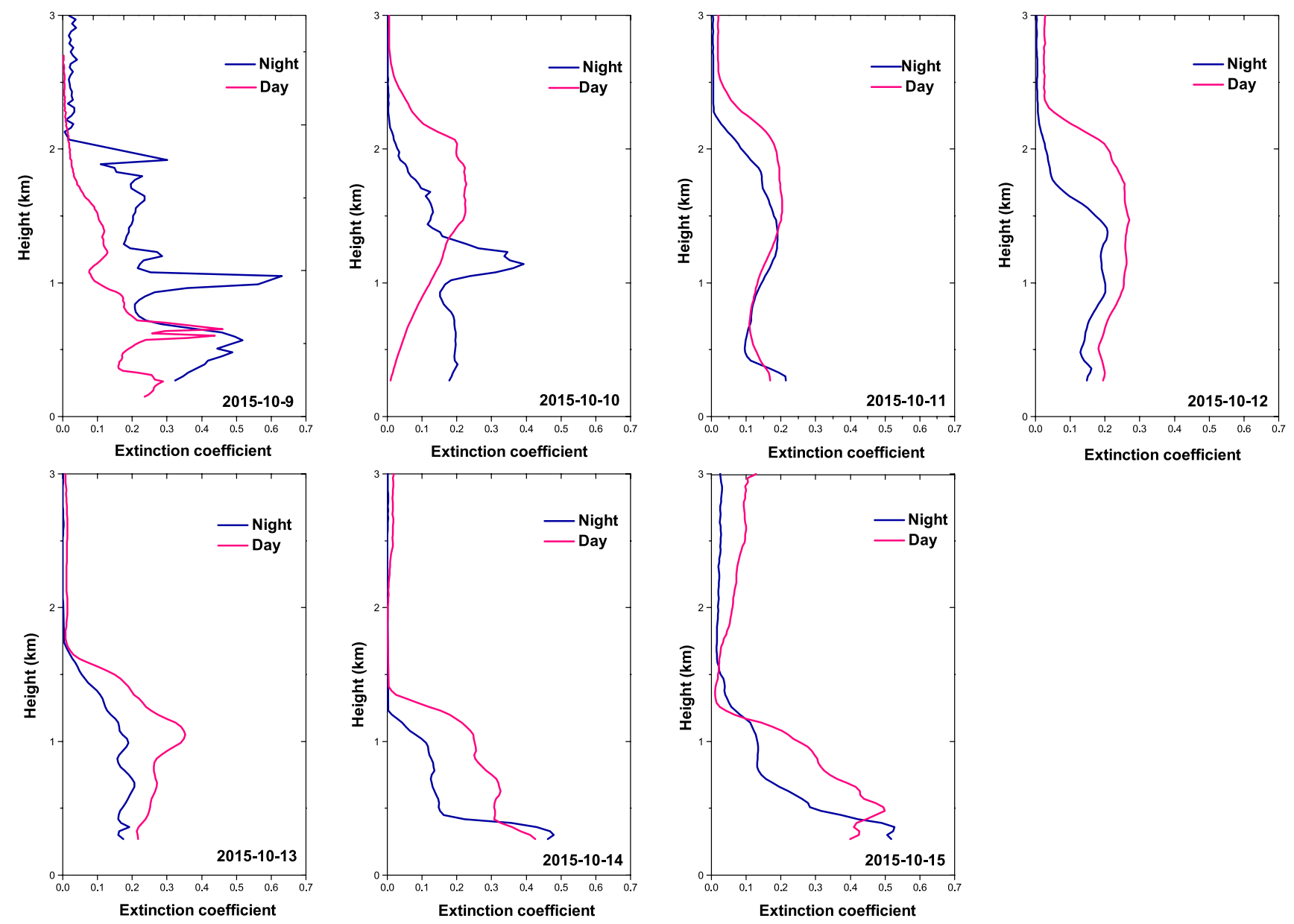

Figure 5. Profiles of the aerosol extinction coefficient from MPL-retrieved data, averaged for daytime and nighttime during 9-15 October 2015 in Hangzhou.

as well, and the peak radius growth from 0.11 to $0.15 \mu \mathrm{m}$ is attributable to the hygroscopic growth, which may help strengthen the scattering ability of the particles (SSA is up to 0.96 at $440 \mathrm{~nm}$ ). The daily averaged AODs at $440 \mathrm{~nm}$ are all above 0.65 during this process. On 15 October, the AOD is close to 1.00 at $440 \mathrm{~nm}$ when the two aerosol layers mix. The SSAs at all four wavelengths continue to increase from 11 to 14 October and decrease on 15 October. The values at $440 \mathrm{~nm}$ vary from 0.95 to around 0.97 . The AAODs show a corresponding variability trend with AOD and the volume of the coarse mode, which dominates the absorbing features. The maximum AAOD at $440 \mathrm{~nm}$ is 0.056 on 12 October, and the minimum is 0.026 on 14 October.

Due to the continuous aerosol-transport signals detected by the MPL during 9-15 October 2015, trajectories over this period were grouped into three clusters, as depicted in Fig. 7a-1. Cluster 1 contributes the maximum proportion of $50.00 \%$ and comes from northern China, via Hebei, western Shandong and Jiangsu provinces, traveling southwards to the YRD region. This cluster relates to the highest $\mathrm{PM}_{2.5}$ con- centration $\left(81.05 \pm 28.18 \mu \mathrm{g} \mathrm{m}^{-3}\right)$. Cluster 2 travels on the lowest and fastest stemming from north of Anhui Province, accounts for $30.95 \%$, and correlates with the $\mathrm{PM}_{2.5}$ concentration of $74.45 \pm 30.17 \mathrm{\mu g} \mathrm{m}^{-3}$. The highest air mass trajectories associated with cluster 3 account for $19.05 \%$ and originate from the eastern edge of Xinjiang at an altitude above $5000 \mathrm{~m}$, also passing through Henan and Anhui provinces to Hangzhou.

The WPSCF reveals the spatial distribution of the probabilities of the potential $\mathrm{PM}_{2.5}$ sources obtained by the HYSPLIT model and $\mathrm{PM}_{2.5}$ concentrations. As shown in Fig. 7a-2, the most likely source areas with WPSCF values for $\mathrm{PM}_{2.5}$ cover most of Henan, Anhui, Jiangsu, and Shandong provinces, in which the WPSCF values are over 0.8 . Figure $7 \mathrm{a}-3$ shows the spatial distribution of the WCWT value, which provides information regarding the relative contribution of source regions potentially affecting $\mathrm{PM}_{2.5}$ $\left(>35 \mu \mathrm{g} \mathrm{m}^{-3}\right.$ ) in Hangzhou, similar to the WPSCF pattern. The northern part of Henan and the western Shandong region (including the south of the Beijing-Tianjin districts), with 

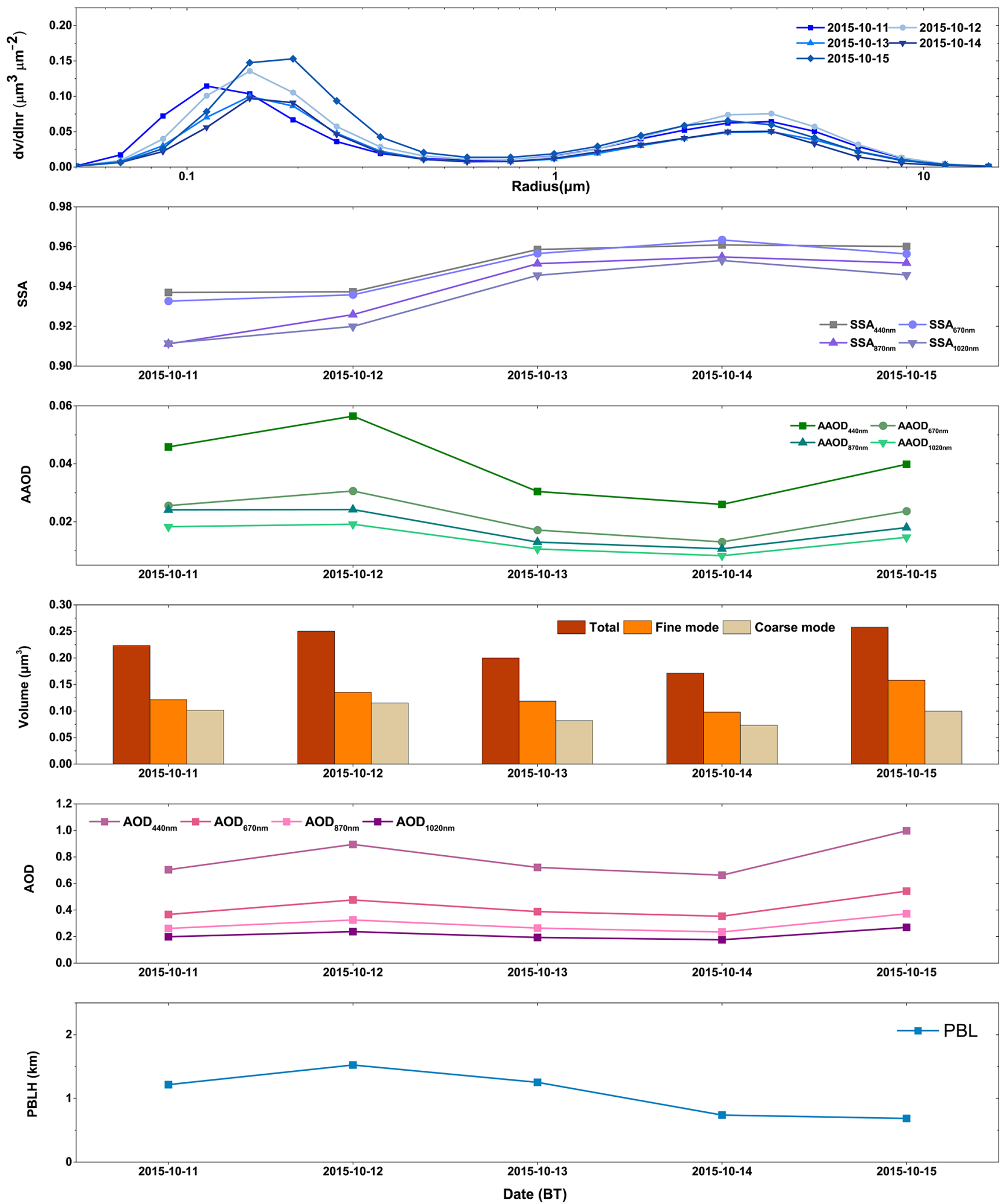

Figure 6. Daily averaged variation in aerosol optical properties and PBLH in Hangzhou during 11-15 October 2015. 

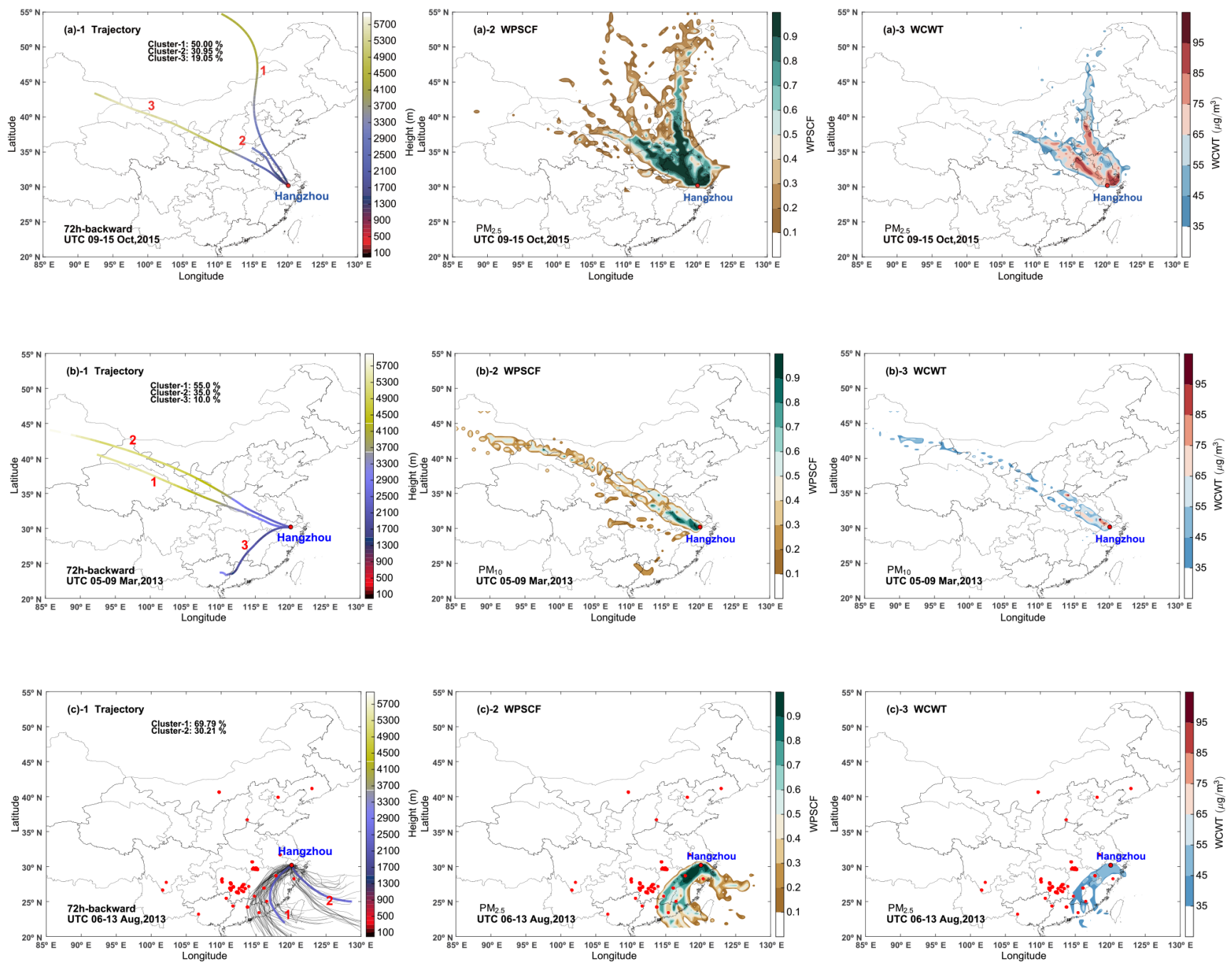

Figure 7. Mean $72 \mathrm{~h}$ backward trajectories of each trajectory cluster and spatial distributions of WPSCF and WCWT values for PM 2.5 in Hangzhou during (a) 9-15 October 2015, (b) 5-9 March 2013, and (c) 6-13 August 2013.

rather high WCWT values $\left(>75 \mu \mathrm{g} \mathrm{m}^{-3}\right)$, is recognized as the area contributing the most $\mathrm{PM}_{2.5}$. Combining the daily spatial distribution of $\mathrm{PM}_{2.5}$ concentrations with AOD from MODIS retrieval data over eastern China (Figs. S1-S2 in the Supplement), districts where the air mass trajectories pass intensively can be seen to have relatively high pollution levels. These include Henan, Hebei, Anhui, and Jiangsu provinces, situated in the North China Plain, which has been recognized as another center of high $\mathrm{PM}_{2.5}$ concentrations (Zhang et al., 2012, 2013). In addition, the pollution scope from the north to the YRD region is becoming wider and more serious day by day.

Furthermore, daily wind fields at $850 \mathrm{hPa}$ (height of about $1.5 \mathrm{~km}$, at which the transport is detected by the MPL) from ECMWF (Fig. S1 in the Supplement) verify the northwest wind prevailing over eastern China during this case, which brought the pollutants from northern China to the YRD re- gion. The wind speed gradually declines, benefiting the formation of stable conditions during the last few days. Note that CALIPSO's acquisition of the aerosol vertical distribution on 14 October is consistent with the above results that an aerosol layer under $2 \mathrm{~km}$ exists over Hangzhou and the areas further north (where intensive trajectories passed over), and it is identified as being in "polluted continental" or "polluted dust" categories (Fig. 8a). Under certain circumstances, however, smoke aerosols can be misidentified as polluted dust aerosols (Xia et al., 2013).

Although a dry, clean northwestern airstream prevails in eastern China during winter (Tao et al., 2012), northern winds near the surface may not be strong enough to blow the pollutants away from eastern China but transport the particle pollutants to the central part of the North China Plain. The continuing northwesterly winds blow particle pollutants to the YRD region (Li et al., 2014; Ming et al., 2017). A similar 

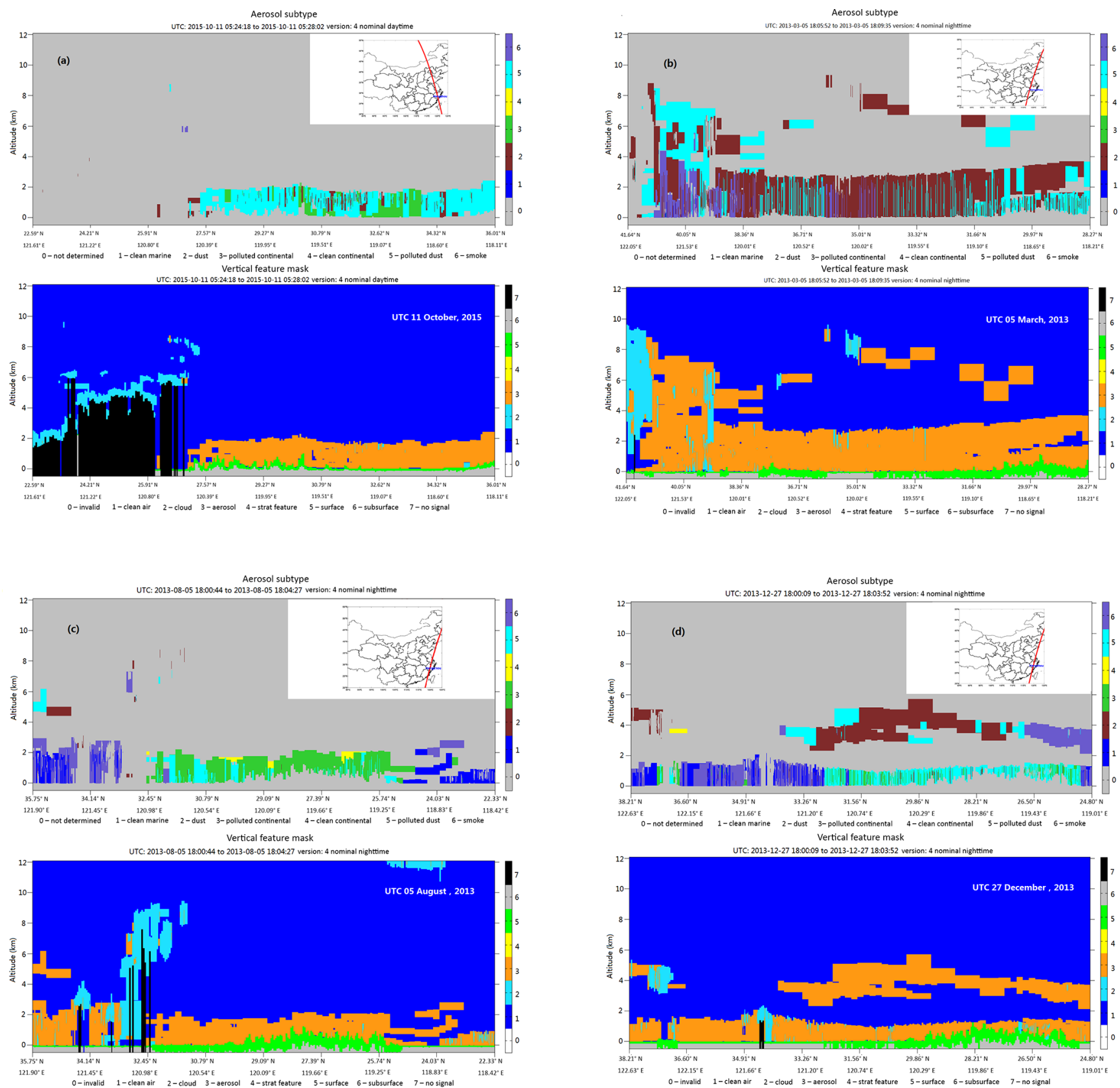

Figure 8. CALIPSO L2 products of vertical feature mask, aerosol subtype, and its ground track on (a) 11 October 2015, (b) 5 March 2013, (c) 5 August 2013, and (d) 27 December 2013.

transport mechanism occurs in this case during 9-15 October 2015 . Northerly pollutant transport at $850 \mathrm{hPa}$ primarily results in an increase in $\mathrm{PM}_{2.5}$ mass concentration, which is facilitated by the occurrence of the descending external aerosol layers, pushed down by the PBL. Pollutants from the North China Plain are dominated by fine particles, which tend towards hygroscopic growth with adequate requisite moisture in the YRD region, increasing the SSA over Hangzhou. As a result, the increasing scattering aerosols transported from haze areas of North China block the solar radiation to the surface, creating a cooling effect. If that is the case, turbulence will correspondingly weaken, and the PBLH will decrease, facilitating the accumulation of pollutants at lower heights. The accumulation of air pollutants can then intensify the scattering ability, forming a positive feedback mechanism. 


\subsubsection{Pollutants transported from desert areas}

Dust events in spring contribute to high AODs, particularly in northern and eastern China (Che et al., 2015b). They are transported over long distances and their influence can be identified on regional and even global scales (Chin et al., 2007; Uno et al., 2009; S. Chen et al., 2017; S. Y. Chen et al., 2017). For instance, Asian dusts are frequently observed in spring and result in air pollution in the downwind areas of East Asia (Kim et al., 2010; Sakai et al., 2002, 2003; Liu et al., 2011; Li, 2015), such as the YRD region, including Nanjing and Shanghai (Yong et al., 2015; Huang et al., 2013).

A series of transported aerosol masses from the northwestern desert area over the YRD region were monitored by the MPL and are seen in the time-height cross section of extinction coefficients at $532 \mathrm{~nm}$ during 5-9 March 2013 in Fig. 4b. Throughout this period, the volume size distributions and particle volumes are strongly dominated by the coarse mode (Fig. 10). The peak radius of the fine mode is around $0.11 \mu \mathrm{m}$ and $1.3 \mu \mathrm{m}$ for the coarse mode. The AOD on 7 March is around 0.88, when the transported aerosol layer is most intense, while the value on 6 March is just 0.47 at $440 \mathrm{~nm}$. Early on $5 \mathrm{March}$, the intensive layer is detected at $1.5 \mathrm{~km}$ and the peak extinction coefficient is around $0.65 \mathrm{~km}^{-1}$, according to the profiles shown in Fig. 9. The SSAs retrieved from the CE-318 are 0.84, 0.91, 0.91, and 0.90 at $440,670,870$, and $1020 \mathrm{~nm}$, respectively, which are lower than those for the northern transported particles. The corresponding AAODs are 0.13, 0.05, 0.04, and 0.04, respectively, which are higher than the values during the northern transportation case. The particles in this case are more strongly absorbing than the type transported from the northern polluted areas discussed in the previous section. The transported mass weakens on the second day until night, when the aerosol layer lies between 1.0 and $2.5 \mathrm{~km}$, with the peak coefficient above $0.4 \mathrm{~km}^{-1}$. Correspondingly, the volumes of both modes decrease, and this is accompanied by a drop in SSA and AAOD to 0.79 and 0.1 , respectively, at the $440 \mathrm{~nm}$ wavelength. During 7-8 March, a thickening of the external aerosol layer is accompanied by a substantial increase in the volume of coarse-mode particles, coinciding with an increased AAOD to 0.15 on 7 March and 0.13 on $8 \mathrm{March}$, at $440 \mathrm{~nm}$. The peak extinction is about $0.2 \mathrm{~km}^{-1}$ above a height of $2 \mathrm{~km}$. On the last day of this case, no external aerosol layer is detected by the MPL (the noisy signals shown in the profiles in Fig. 9 may result from an instrumental malfunction), and the absorption weakens due to the reduced volume. Note that the SSAs show little change during the last three days, which implies that SSA may not be sensitive to the variation of particles in the dominant coarse mode. Meanwhile, the PBLH above the aerosol layer varies from $2.0 \mathrm{~km}$ to about $3 \mathrm{~km}$ continuously in this case, dissipating the transported dust particles and causing the peak extinction coefficients to decrease each day.
Table 1. Trajectory number and PM mean concentration of each cluster in Hangzhou during three cases, including case 1 (transportation from haze area of North China), case 2 (transportation from northwestern dust area), and case 3 (transportation from southern biomass-burning area).

\begin{tabular}{lrrr}
\hline Case & Cluster & Number & Mean $\left(\mu \mathrm{g} \mathrm{m}^{-3}\right)$ \\
\hline 1 & 1 & 41 & $81.05 \pm 28.18$ \\
& 2 & 22 & $74.45 \pm 30.17$ \\
& 3 & 9 & $76.11 \pm 35.51$ \\
2 & 1 & 12 & $71.08 \pm 60.00$ \\
& 2 & 7 & $84.57 \pm 18.26$ \\
3 & 1 & 61 & $54.52 \pm 16.63$ \\
& 2 & 26 & $39.04 \pm 10.14$ \\
\hline
\end{tabular}

From the CALIPSO L2 retrieval results of vertical feature mask and aerosol subtypes (illustrated in Fig. 8b), a $3 \mathrm{~km}$ thick aerosol layer can be seen on 5 March 2015 in the northwestern upwind areas of the YRD, with a mixture of dust and polluted dust. After this, a thin external layer is detected.

Assuming that the extraneous aerosol layer was dust, based on the in situ and satellite observations, $72 \mathrm{~h}$ backward trajectory analysis was applied to determine the source of the dust. Since the dust aerosol layer is most intense at $2 \mathrm{~km}$, the start location of the trajectory calculation was set to be $2000 \mathrm{~m}$. Figure $7 \mathrm{~b}-1$ shows three cluster trajectories changing with height. The air masses associated with cluster 1 , accounting for $55 \%$, originate from the Gurbantünggüt Desert lying in northern Xinjiang, and they move southeasterly over the Gobi Desert, which agrees with the results from Bi et al. (2017), and the Badain Jaran Desert located in Inner Mongolia. This trajectory is similar to the dust pathway to Xi'an described by Wang et al. (2006b). The air masses associated with cluster 2 , accounting for $35 \%$, follow parallel paths from the Kumtag Desert in western Xinjiang, and they pass over the Loess Plateau. The cluster 3 stems from Guangxi Province at an altitude below $3000 \mathrm{~m}$ and does not pass over a desert area.

The number of trajectories in each cluster and the corresponding $\mathrm{PM}_{10}$ mean concentrations for all trajectories are summarized in Table 1 . Based on the mean $\mathrm{PM}_{10}$ concentrations in each cluster, clusters 1 and 2 take the most primary role in bringing dust to the YRD region. Combining the distribution of WPSCF and WCWT values, the sources most likely to affect the YRD are located in the deserts of northwestern China, collectively termed the "Western High-Dust Desert" (Zhang et al., 1998), which include the Gurbantünggüt Desert, the Gobi Desert, and the Badain Jaran Desert, covered by cluster 1 . From the intensive trajectories' pathways, Henan and Anhui provinces also appear to be highly likely source regions located upwind of the YRD, which just corresponds to the vertical feature mask from the CALIPSO L2 products that show a mixed layer of dust and polluted 

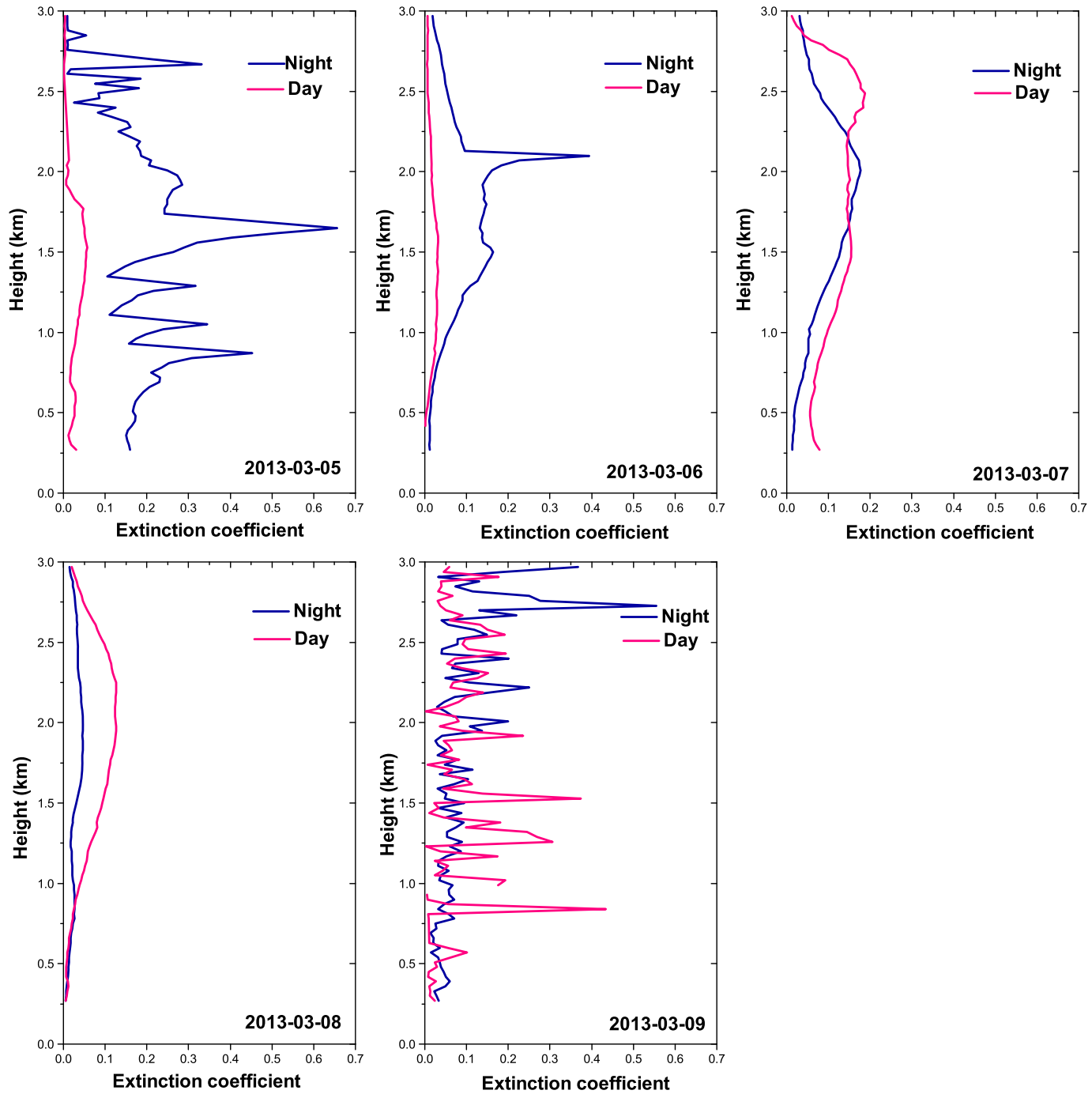

Figure 9. Profiles of aerosol extinction coefficient from MPL-retrieved data averaged for daytime and nighttime during 5-9 March 2013 in Hangzhou.

dust in Anhui Province. The WCWT results make the potential sources explicit. The Gobi Desert and Henan and Anhui provinces are prominent sources of dust transported to Hangzhou.

The daily spatial distributions of $\mathrm{PM}_{10}$ concentrations and wind fields at $750 \mathrm{hPa}$ in eastern China during 5-9 March 2013 are shown in Fig. S3 in the Supplement. The in situ mean $\mathrm{PM}_{10}$ concentration on 5 March is between 200 and $250 \mu \mathrm{g} \mathrm{m}^{-3}$, while for the remaining days it is between 150 and $200 \mu \mathrm{g} \mathrm{m}^{-3}$ in Hangzhou. The wind fields at $750 \mathrm{hPa}$ show northerly and northwesterly winds during 5-8 March 2013, consistent with the primary trajectories to Hangzhou at a height of $2 \mathrm{~km}$. The second day, 6 March, shows the lowest wind speed, coinciding with minimal horizontal transport during that day, as can be seen in the time-height cross section of the MPL extinction coefficient (Fig. 4b). The wind speed over the next two days increases, as does the trans- port. On the last day, the wind direction turns southwesterly at $750 \mathrm{hPa}$, which may bring the clean air from the sea to Hangzhou. The wind direction on 9 March is consistent with the existence of cluster 3 , which carries little $\mathrm{PM}_{10}$ mass and only accounts for $10 \%$ among the trajectories.

In spring, the long-range transport of dust aerosols from desert regions not only has an impact on northwestern cities such as Xi' an (Wang et al., 2006b), or cities in the north of eastern China such as Beijing, Xianghe, and Shenyang (Xin et al., 2010; Zhang et al., 1998), but also on cities in the YRD region such as Nanjing, Shanghai (Zhang et al., 2016), and Hangzhou. When transported dust particles dominate in the ambient atmosphere over the YRD region, the aerosol optical properties show a relatively high level of absorptive features, much stronger than in aerosols transported from the north. These particles mostly come from moving air masses loaded with dust particles from desert regions located in northwest- 

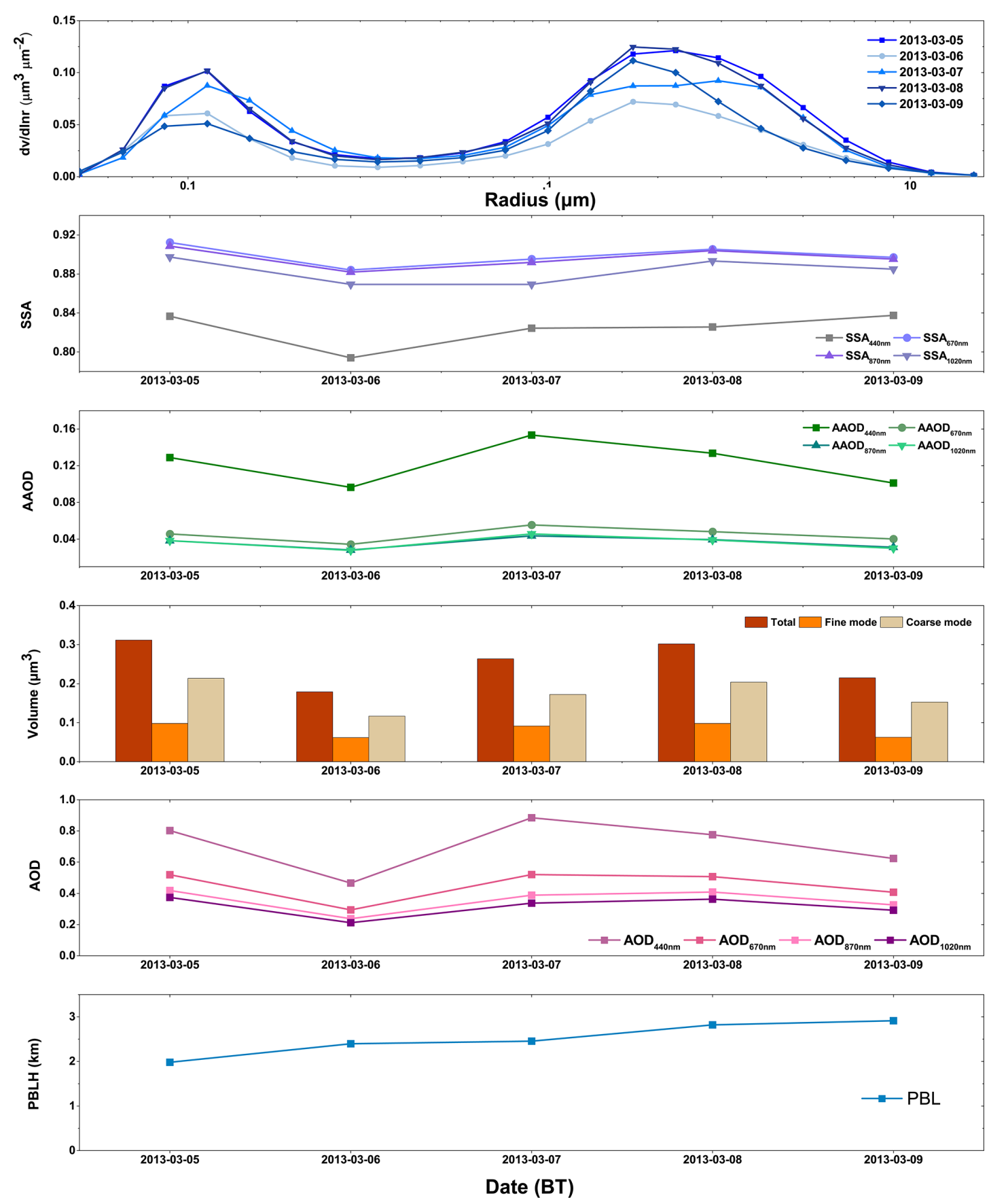

Figure 10. Daily averaged variation in aerosol optical properties and the PBLH in Hangzhou during 5-9 March 2013.

ern China. During the days dust transport enhanced, absorptive dust particles increase AOD and AAOD over Hangzhou and heat the atmosphere to facilitate turbulence, leading the PBL to rise in the same day, which will accelerate the diffusion in the following days.

\subsubsection{Pollutants transported from biomass-burning areas}

Since the lowest values of SSA occur in August, the aerosol particles over Hangzhou exhibit strong absorption characteristics in that month. Figure $4 \mathrm{c}$ illustrates the time-height cross section of extinction coefficient retrieved from the MPL during the transportation of biomass-burning emissions to Hangzhou, and it shows little contribution from local emis- 

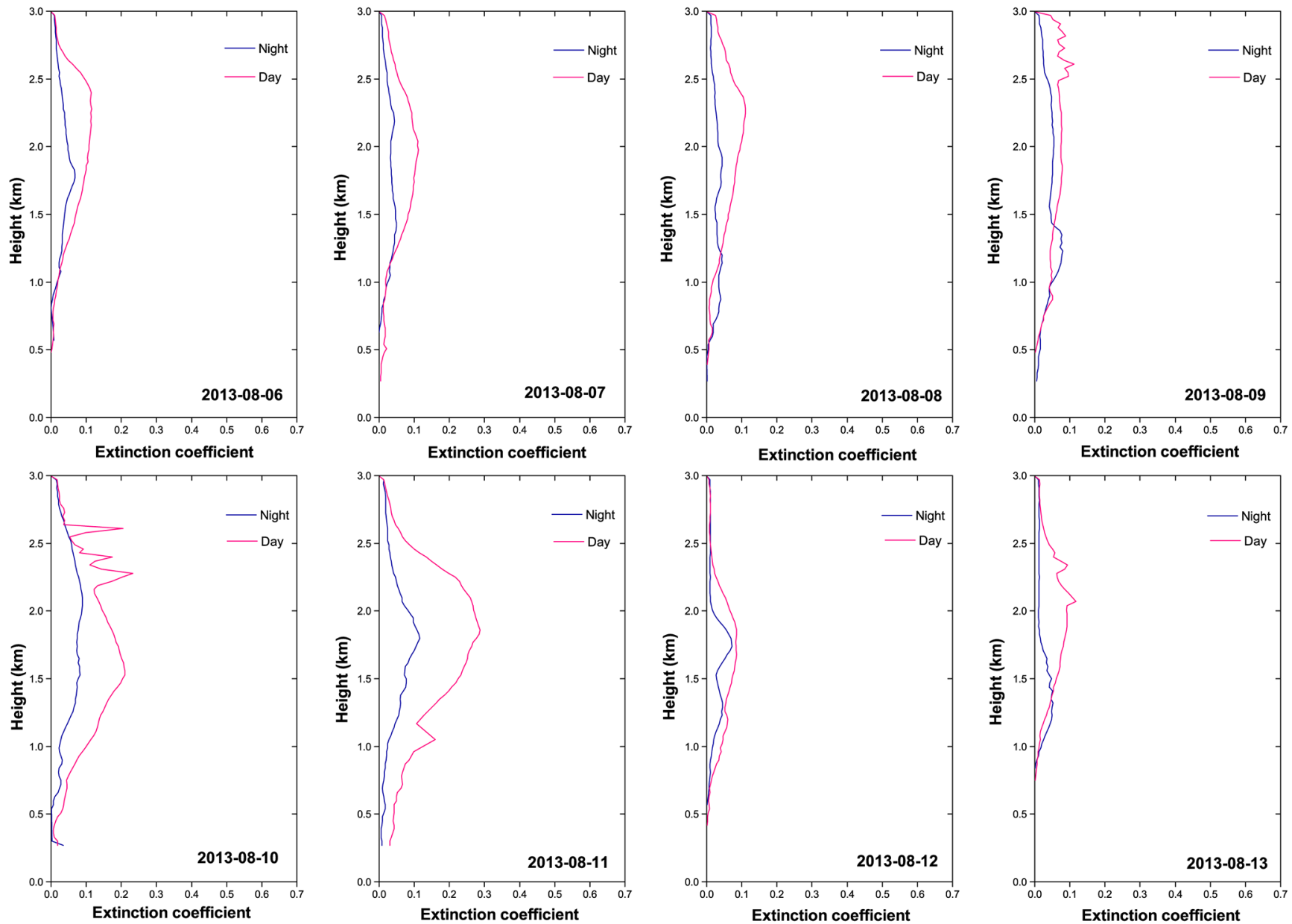

Figure 11. Profiles of the aerosol extinction coefficient from MPL-retrieved data averaged for daytime and nighttime during 6-13 August 2013 in Hangzhou.

sions. In the first four days, the external aerosols are concentrated at 1.5 to $2 \mathrm{~km}$ and the peak extinctions are less than $0.2 \mathrm{~km}^{-1}$, even during the daytime (Fig. 11). In the meantime, the PBLH varies from 2.45 to $2.93 \mathrm{~km}$, above the transported aerosol layer. Over 10-11 August, the external fine particles are noticeably enhanced, with the PBLH decreasing to $2.30 \mathrm{~km}$. Consequently, the layer develops downwards, to a height of around $1 \mathrm{~km}$, which may imply a tendency towards sedimentation. Maximum extinctions exceed $0.2 \mathrm{~km}^{-1}$ and even reach $0.3 \mathrm{~km}^{-1}$ during the daytime on 11 August. The transport tends to die down and deposit over 12-13 August, with a higher PBL, thinner aerosol layer, and lower coefficients (below $0.1 \mathrm{~km}^{-1}$ ). The whole process of this transportation is not as strong as the northern transport process. During 6-9 August, AOD values (retrieved from the CE-318) are below 0.5. They increase to 0.75 when the maximum extinction occurs over 11-12 August and decrease when diffusion and sedimentation contribute. Combined with other aerosol optical properties, fine-mode particles are remarkably dominant during the whole process in terms of the volume and size distribution (Fig. 12). However, the mass concentration is far less than during the northern transported pollution of 11-15 October 2015. In this case, the total volumes are below $0.1 \mu \mathrm{m}^{3}$ for most of the days, except for the two enhanced transport days in which the total volume exceeds $0.12 \mu \mathrm{m}^{3}$. The SSAs keep increasing until a peak value of between 0.73 and 0.898 was reached at $440 \mathrm{~nm}$ before the last two days, which suggests that the increase in external fine particles enhances the scattering ability. The values are similar to the SSAs observed from biomass-burning emissions in the African savanna, Zambia, during 1995-2000 (Dubovik et al., 2002). The AAODs are almost above 0.09 at $440 \mathrm{~nm}$ during this period, which is higher than those seen in the northern transported pollution. It is suggested that the particles brought by these air masses are in the fine mode, with strong absorption characteristics, which is indicative of smoke aerosol.

To determine the pollution source, trajectories and primary clusters are depicted in Fig. 7c-1, with the backwardtrajectory start locations set to 1000,1500 , and $2000 \mathrm{~m}$. Con- 

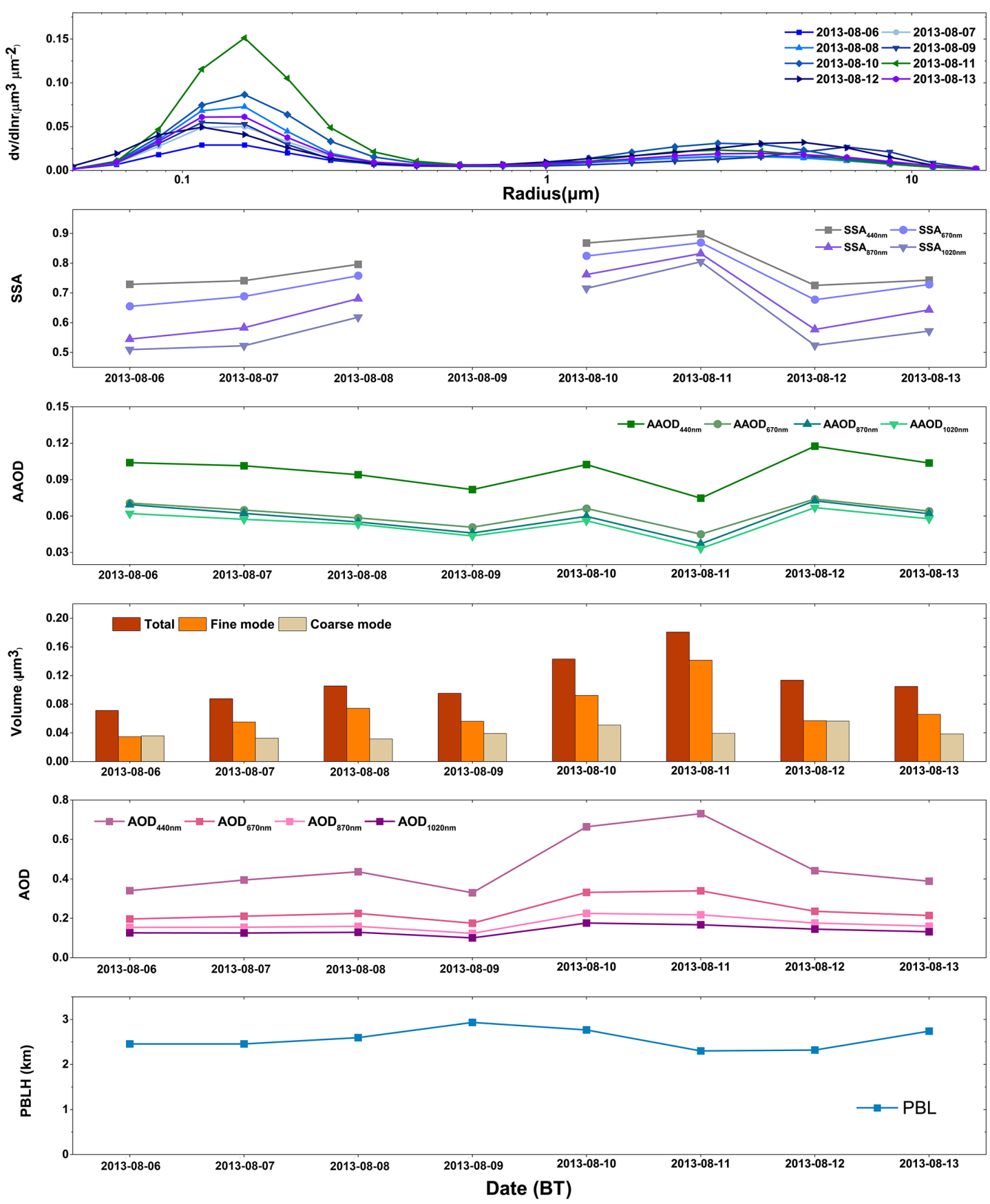

Figure 12. Daily averaged variation of aerosol optical properties and PBLHs in Hangzhou during 6-13 August 2013.

sidering the significant absorptive ability of aerosol particles transported over Hangzhou, we apply the fire hotspot information (90\% confidence) from MODIS Collection 6 and VIIRS $375 \mathrm{~m}$ to analyze the possible source of this type of particle. It is assumed that the external particles during these days were created from biomass burning, which is the major source of atmospheric light-absorbing organic carbon and black carbon aerosols, contributing around $42 \%$ of the global black carbon emissions (Bond et al., 2004,
2013; Cao et al., 2005). Combining the fire hotspots detected by MODIS with the trajectory analysis, the majority of trajectories (accounting for $69.79 \%$ ), which are associated with cluster 1 , travel northeasterly to the YRD region, passing over fire hotspots located in Guangdong, Fujian, Jiangxi, and Zhejiang provinces, with a mean $\mathrm{PM}_{2.5}$ concentration of $54.52 \pm 16.63 \mu \mathrm{g} \mathrm{m}^{-3}$. According to the study of Chan (2017), not only do the biomass-burning emissions have local impacts, but they can also be transported intercon- 
tinentally and influence the atmospheric system on a global scale. The air masses associated with cluster 2 originate from the sea to the southeast, only passing one spot lying in southern Zhejiang with a mean $\mathrm{PM}_{2.5}$ concentration of $39.04 \pm 10.14 \mu \mathrm{g} \mathrm{m}^{-3}$, bringing clean air from over the sea to Hangzhou during 12-13 August (Fig. S5 in the Supplement).

With reference to the WPSCF and WCWT results, the locations of the potential sources are almost consistent with the regions where fire hotspots are detected or biomass burning occurs, including the eastern part of Guangdong and Jiangxi provinces, western Fujian, and most of Zhejiang. The occurrence of biomass burning in these areas has been studied previously (Wang and Zhang, 2008). With regard to the retrieval results of the vertical feature mask and aerosol subtype from CALIPSO on 5 August (Fig. 8c), the intensive aerosol layer exists below $2 \mathrm{~km}$ along the CALIPSO path southwest of Hangzhou. The aerosol types are mostly identified as being in polluted continental or polluted dust categories over and southwest of Hangzhou, which coincides with the backward trajectories carrying pollutants from the fire hotspots during 6-13 August 2013. As has been noted, the retrieval results from CALIPSO may misidentify the smoke aerosols as polluted dust, but for the majority of days during this case satellite retrieval data verify the results from CALIPSO.

The aerosol transported from the southern biomassburning areas to Hangzhou shows a capacity for strong light absorption and is dominated by the fine mode. The external aerosol layers observed in the vertical distribution of the extinction coefficient appear around $1-2 \mathrm{~km}$, with the maximum value at $0.3 \mathrm{~km}^{-1}$. The backward trajectory and potential source analysis determines the likely sources. Satellite retrieval results (both MODIS and CALIPSO) verify that the transported aerosol originates from biomass-burning regions, and this is consistent with the aerosol optical properties retrieved from the CE-318 in Hangzhou. In addition, previous studies have shown that aerosol absorption depends on the mixing mechanism of soot with other aerosol components (Ackerman and Toon, 1981; Martins et al., 1998; Jacobson, 2001), so the situation that occurs during 6-13 August 2013 is not unique to the YRD region.

\subsubsection{Pollutants emitted from local emissions}

While aerosols transported from the northern, southern, or desert areas contribute much to the ambient atmospheric pollution in the YRD region, a high concentration of aerosols with diverse properties are also emitted locally (Chen et al., 2012; Zhuang et al., 2015; Liu et al., 2015).

Figure $4 \mathrm{~d}$ shows a series of successive local emissions in the time-height cross section of the extinction coefficient obtained by the MPL, during 27-29 December 2013. The PBLH varies from 1.16 to $0.72 \mathrm{~km}$ during this period. It can be seen that the aerosol is composed of two layers, distributed below and above the PBL. An external aerosol layer can be seen at $1-1.5 \mathrm{~km}$, while the layer caused by local emissions lies below $1 \mathrm{~km}$, and even below $0.5 \mathrm{~km}$, due to the stable PBL that exists over cold surfaces, particularly in the wintertime (Medeiros et al., 2005). From the vertical profiles of the extinction coefficient in Fig. 13, on 27 December 2013 the peak extinction of the local emissions layer is seen, at around 0.1 and $0.15 \mathrm{~km}^{-1}$ in the nighttime and daytime, respectively. The two separated layers mix downwards on the second day, so that the profiles barely show the separation between them, and the maximum extinction coefficient reaches $0.2 \mathrm{~km}^{-1}$ below $0.5 \mathrm{~km}$. On 29 December, an intensification is seen both in aerosols transported at higher altitudes and in those emitted locally, and the peak coefficient for the local emissions layer is close to $0.4 \mathrm{~km}^{-1}$ during the daytime and $0.2 \mathrm{~km}^{-1}$ at night.

The AODs retrieved from CE-318 vary from 0.4 to 0.55 , according to the results presented in Fig. 14. The volume size distribution during these three days shows a strong bimodal pattern, with the peak volumes at radii of 0.11 and $2.94 \mu \mathrm{m}$ for fine and coarse modes, respectively. Coarse particles noticeably dominate on 27 December, with an SSA of 0.89 at $440 \mathrm{~nm}$ - lower than the value at other wavelengths. Meanwhile, satellite retrieval results of vertical feature mask and aerosol subtype from CALIPSO (Fig. 8d) verify the dominance of the coarse mode on 27 December. The L2 products confirm the existence of an aerosol layer below $2 \mathrm{~km}$, and identify it as being a mixture of polluted dust and polluted continental categories over the YRD region. Furthermore, another layer identified as "dust" exists between the heights of 3 and $5 \mathrm{~km}$ (beyond the detection range of the MPL), composed of high-volume coarse-mode particles, which may have an influence on the lower polluted dust layer. Over the next two days, the volume of the two modes become more balanced due to enhanced transport and emissions, and the SSAs at $440 \mathrm{~nm}$ show an inverse relationship to the values at other wavelengths. On 29 December, the lowest value of SSA $(440 \mathrm{~nm})$, at 0.88 , and the highest value of AAOD $(440 \mathrm{~nm})$, at 0.073 , is seen. The maximum SSA value in this case is higher than the peak SSA observed when desert transport occurs but lower than the peak value seen with the strong biomass-burning transport. The aerosol optical properties of mixed fine- and coarse-mode particles are different from when one mode dominates.

With reference to the spatial distribution of $\mathrm{PM}_{2.5}$ mass concentration and the wind field at $10 \mathrm{~m}$ from the surface (Fig. S5), the enhanced emissions seen in the extinction coincide with an increase in the in situ observed PM concentration during 28-29 December. The wind is low within the PBL due to the weakening of atmospheric circulation in northern China during winter (Tao et al., 2016). Consequently, the low wind speed at the surface contributes to the accumulation of aerosol particles, resulting in an increase in pollutant concentrations over these days.

Pollutants emitted locally stay below $0.5 \mathrm{~km}$ during $27-$ 29 December 2013 in the YRD region. Facilitated by the 

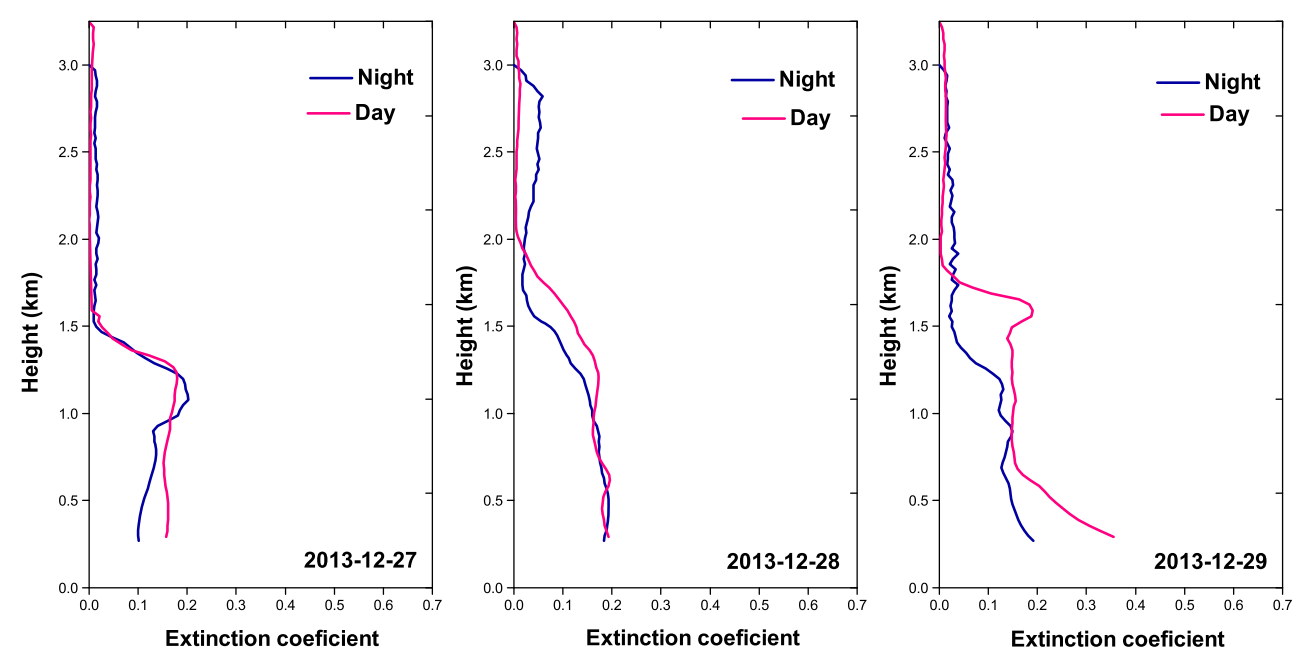

Figure 13. Profiles of aerosol extinction coefficient from MPL-retrieved data averaged for daytime and nighttime during 27-29 December 2013 in Hangzhou.

low wind speed at the surface and the downward transport of external dust aerosols, aerosol optical properties show weaker absorption than the strong biomass-burning aerosol and weaker scattering than transported dust aerosols.

\section{Conclusion}

Based on long-term ground-based lidar and sun-photometer observations, variations in monthly averaged aerosol properties and PBLHs during 2013-2015 in the YRD region are presented and discussed. Combining satellite remote sensing data from CALIPSO and MODIS, backward trajectories, and PSCF and CWT analyses, four typical transportation mechanisms are analyzed under enhanced haze pollution events in the YRD region.

For the long-term monthly variation of aerosol optical properties in the YRD region, it is found that fine and scattering particles dominate, except in March. The $\mathrm{PM}_{2.5}: \mathrm{PM}_{10}$ ratio is high, $\mathrm{AE}_{440-870 \mathrm{~nm}}$ is above 0.8, and SSA exceeds 0.85 during most months. Due to the low-altitude and stable PBL in the colder months (from September to February), PM mass concentrations in January, November, and December are high. Conversely, the lower PM concentrations occur during the warmer months (from March to August), partly due to a higher PBL attributed to a stronger diurnal cycle, but also due to higher precipitation in July and August. The AOD is generally high, implying severe aerosol loading in the YRD. As for the mixed type of aerosol in the YRD, the volume size distributions show a bimodal logarithmic normal structure, except in June and September, when it appears trimodal due to hygroscopic growth. The highest SSA is also seen during these months.

During northern aerosol transportation, particles from polluted areas in North China are seen at a height of about
$1-1.5 \mathrm{~km}$, within the PBL, and they are dominated by the fine mode, with $\mathrm{AOD}_{440 \mathrm{~nm}}$ above 0.65 and $\mathrm{SSA}_{440 \mathrm{~nm}}$ varying from 0.95 to 0.97 . A rising SSA indicates an increase in transported scattering particles, which decrease the radiation to the surface and cool the surface. The weakening turbulence and the declining PBL lowers the aerosol layer, and pollutants accumulate at lower altitudes, thereby concentrating the scattering particles and forming a positive feedback mechanism.

Although dust transport to the YRD is seasonal and infrequent, it does make a difference to the YRD's aerosol loading. Dust air masses around $2 \mathrm{~km}$ are transported from the northwestern desert regions including the Gurbantünggüt Desert, the Gobi Desert, and the Badain Jaran Desert, and they diffuse vertically with the rising PBL. A significant increase in the coarse mode at high altitudes brings about high concentrations of $\mathrm{PM}_{10}$ and higher $\mathrm{AAOD}_{440 \mathrm{~nm}}$, illustrating the stronger absorptive feature of transported dust compared to the northern pollutants transported over the YRD region. And the transported absorptive dust particles heat the atmosphere, raising the PBL over the YRD region to accelerate the diffusion in the PBL.

Biomass-burning pollutants also bring about a seasonal contribution to the aerosol loadings over the YRD region. In the case of biomass-burning transportation, backward trajectories are consistent with the fire hotspots located in Guangdong, Fujian, Jiangxi, and Zhejiang provinces south of the YRD, bringing absorptive fine particles to heights of about $1.5 \mathrm{~km}$ over that region. The SSAs on most days are lower than 0.8 (except one day when the maximum $\operatorname{SSA}_{440 \mathrm{~nm}}$ is 0.898 ), indicating that the biomass-burning pollutants transported from the southwest to the YRD can strengthen the absorptive ability in the ambient atmosphere over the YRD. 

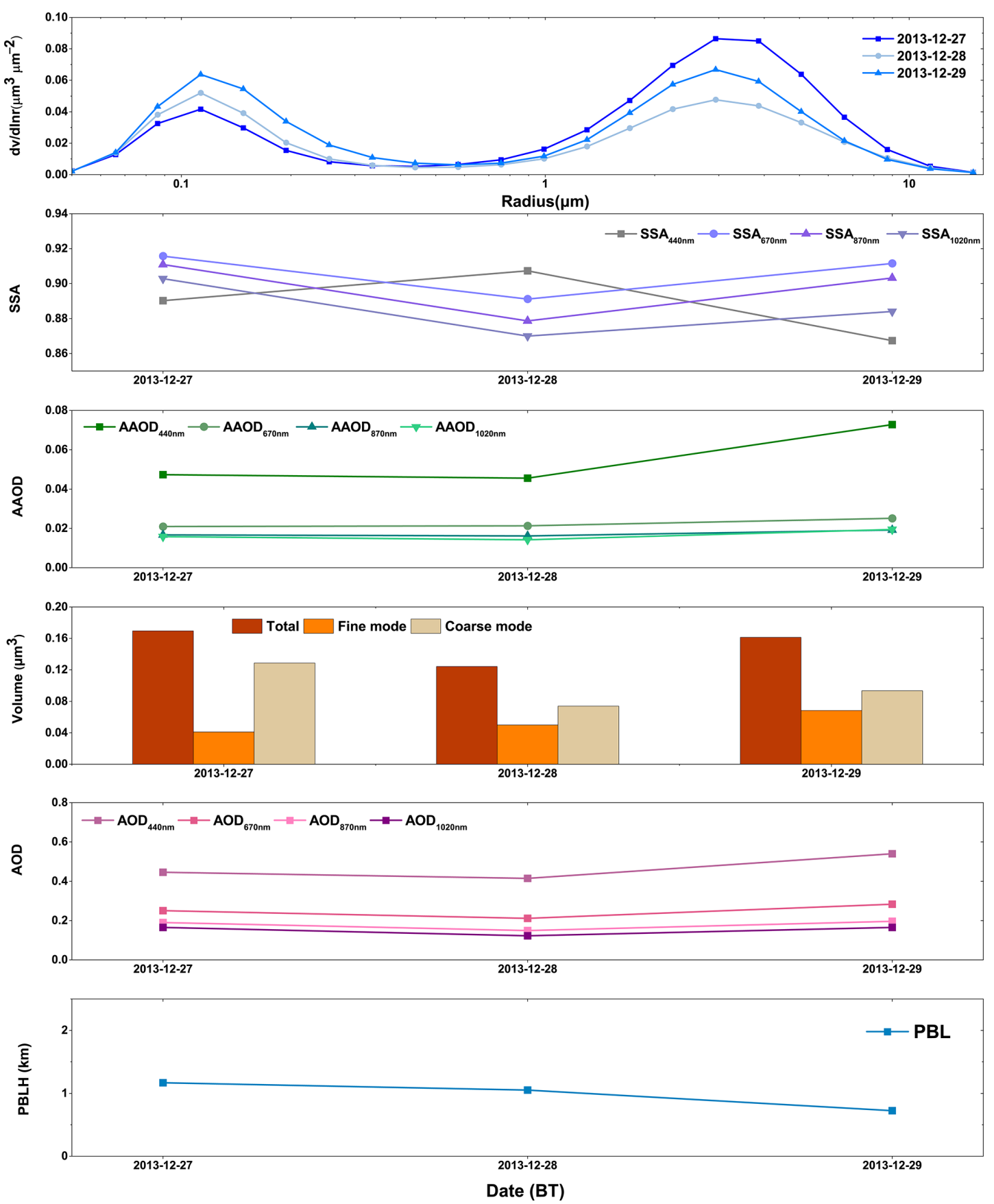

Figure 14. Daily averaged variation in aerosol optical properties and the PBLH in Hangzhou during 27-29 December 2013.

The accumulation of locally emitted pollutants is facilitated by the low wind speed at the surface $(10 \mathrm{~m})$. During the locally emitted aerosol case, the local aerosol layer appears below $1 \mathrm{~km}$, and the low surface wind provides no external transport. The mixture of locally emitted aerosols and dust particles transported downwards shows weaker absorption than the biomass-burning products and weaker scattering than the transported dust aerosols, with the $\mathrm{SSA}_{440 \mathrm{~nm}}$ varying from 0.86 to 0.91 .
The haze pollution events that occur in the YRD region are not only affected by local emissions but can also be contributed to by regional transport, including pollutants from North China, dust aerosols from the northwestern deserts, and strong absorptive particles from southern biomass-burning areas. Therefore, air quality control should focus not only on local emissions reduction, but also on regional emissions. 
Data availability. The datasets can be obtained from the corresponding author upon request.

Supplement. The supplement related to this article is available online at: https://doi.org/10.5194/acp-18-2949-2018-supplement.

Competing interests. The authors declare that they have no conflict of interest.

Special issue statement. This article is part of the special issue "Regional transport and transformation of air pollution in eastern China". It is not associated with a conference.

Acknowledgements. This work was supported by a grant from the National Key Project of MOST (2016YFC0203306), the National Key R\&D Program Pilot Projects of China (2016YFA0601901), the National Key R\&D Program of China (2016YFC0200403), the National Natural Science Foundation of China (41590874\&41375153), the Natural Science Foundation of Zhejiang Province (LY16010006), the CAMS Basis Research Project (2016Z001 and 2014R17), the Climate Change Special Fund of CMA (CCSF201504), the CAMS Basic Research Project (2014R17), the Special Project of Doctoral Research supported by Liaoning Provincial Meteorological Bureau (D201501), and the Hangzhou Science and Technology Innovative project (20150533B17). The authors would like to thank the anonymous reviewers and the editor for their constructive suggestions and comments.

Edited by: Tong Zhu

Reviewed by: two anonymous referees

\section{References}

Ackerman, T. P. and Toon, O. B.: Absorption of visible radiation in atmosphere containing mixtures of absorbing and nonabsorbing particles, Appl. Optics, 21, 3661-3667, 1981.

Adachi, K., Freney, E. J., and Buseck, P. R.: Shapes of internally mixed hygroscopic aerosol particles after deliquescence, and their effect on light scattering, Geophys. Res. Lett., 38, 142-154, 2015.

Bi, J., Huang, J., Hu, Z., Holben, B. N., and Guo, Z.: Investigating the aerosol optical and radiative characteristics of heavy haze episodes in Beijing during January of 2013, J. Geophys. Res.Atmos., 119, 9884-9900, 2015.

Bi, J., Huang, J., Shi, J., Hu, Z., Zhou, T., Zhang, G., Huang, Z., Wang, X., and Jin, H.: Measurement of scattering and absorption properties of dust aerosol in a Gobi farmland region of northwestern China - a potential anthropogenic influence, Atmos. Chem. Phys., 17, 7775-7792, https://doi.org/10.5194/acp17-7775-2017, 2017.

Bond, T. C., Streets, D. G., Yarber, K. F., Nelson, S. M., Woo, J. H., and Klimont, Z.: A technology-based global inventory of black and organic carbon emissions from combustion, J. Geophys. Res.-Atmos., 109, 1149-1165, 2004.

Bond, T. C., Doherty, S. J., Fahey, D. W., Forster, P. M., Berntsen, T., Deangelo, B. J., Flanner, M. G., Ghan, S., Kärcher, B., and Koch, D.: Bounding the role of black carbon in the climate system: a scientific assessment, J. Geophys. Res.Atmos., 118, 5380-5552, 2013.

Cao, J., Shen, Z., Chow, J. C., Qi, G., and Watson, J. G.: Seasonal variations and sources of mass and chemical composition for $\mathrm{PM}_{10}$ aerosol in Hangzhou, China, Particuology, 7, 161-168, 2009.

Cao, J. J., Wu, F., Chow, J. C., Lee, S. C., Li, Y., Chen, S. W., An, Z. S., Fung, K. K., Watson, J. G., Zhu, C. S., and Liu, S. X.: Characterization and source apportionment of atmospheric organic and elemental carbon during fall and winter of 2003 in Xi'an, China, Atmos. Chem. Phys., 5, 3127-3137, https://doi.org/10.5194/acp-5-3127-2005, 2005.

Chan, C. K. and Yao, X.: Air pollution in mega cities in China, Atmos. Environ., 42, 1-42, 2008.

Chan, K. L.: Biomass burning sources and their contributions to the local air quality in Hong Kong, Sci. Total Environ., 212, 596597, 2017.

Chauvigné, A., Sellegri, K., Hervo, M., Montoux, N., Freville, P., and Goloub, P.: Comparison of the aerosol optical properties and size distribution retrieved by sun photometer with in situ measurements at midlatitude, Atmos. Meas. Tech., 9, 4569-4585, https://doi.org/10.5194/amt-9-4569-2016, 2016.

Che, H., Xia, X., Zhu, J., Li, Z., Dubovik, O., Holben, B., Goloub, P., Chen, H., Estelles, V., Cuevas-Agulló, E., Blarel, L., Wang, H., Zhao, H., Zhang, X., Wang, Y., Sun, J., Tao, R., Zhang, X., and Shi, G.: Column aerosol optical properties and aerosol radiative forcing during a serious haze-fog month over North China Plain in 2013 based on ground-based sunphotometer measurements, Atmos. Chem. Phys., 14, 2125-2138, https://doi.org/10.5194/acp-14-2125-2014, 2014

Che, H., Zhang, X.-Y., Xia, X., Goloub, P., Holben, B., Zhao, H., Wang, Y., Zhang, X.-C., Wang, H., Blarel, L., Damiri, B., Zhang, R., Deng, X., Ma, Y., Wang, T., Geng, F., Qi, B., Zhu, J., Yu, J., Chen, Q., and Shi, G.: Ground-based aerosol climatology of China: aerosol optical depths from the China Aerosol Remote Sensing Network (CARSNET) 2002-2013, Atmos. Chem. Phys., 15, 7619-7652, https://doi.org/10.5194/acp15-7619-2015, 2015a.

Che, H., Zhao, H., Wu, Y., Xia, X., Zhu, J., Wang, H., Wang, Y., Sun, J., Yu, J., and Zhang, X.: Analyses of aerosol optical properties and direct radiative forcing over urban and industrial regions in Northeast China, Meteorol. Atmos. Phys., 127, 345354, 2015b.

Che, H. Z., Wang, Y. Q., Sun, J. Y., Zhang, X. C., Zhang, X. Y., and Guo, J. P.: Variation of aerosol optical properties over the Taklimakan Desert in China, Aerosol Air Qual. Res., 13, 777785, 2013.

Chen, J., Jiang, H., Wang, B., Xiao, Z., Jiang, Z., Zhou, G., and Yu, S.: Aerosol optical properties from sun photometric measurements in Hangzhou district, China, Int. J. Remote Sens., 33, 2451-2461, 2012.

Chen, S., Huang, J., Qian, Y., Zhao, C., Kang, L., Yang, B., Wang, Y., Liu, Y., Yuan, T., and Wang, T.: An overview of min- 
eral dust modeling over East Asia, J. Meteorol. Res.-P.R.C., 31, 633-653, 2017.

Chen, S. Y., Huang, J. P., Li, J. X., Jia, R., Jiang, N. X., Kang, L. T., Ma, X. J., and Xie, T. T.: Comparison of dust emissions, transport, and deposition between the Taklimakan Desert and Gobi Desert from 2007 to 2011, Sci. China Earth Sci., 60, 1338, https://doi.org/10.1007/s11430-016-9051-0, 2017.

Chen, Z., Cheng, L., Liu, W., Zhang, T., and Jin, X.: A synchronous observation of enhanced aerosol and $\mathrm{NO}_{2}$ over Beijing, China, in winter 2015, Sci. Total Environ., 575, 29-436, 2017.

Chin, M., Diehl, T., Ginoux, P., and Malm, W.: Intercontinental transport of pollution and dust aerosols: implications for regional air quality, Atmos. Chem. Phys., 7, 5501-5517, https://doi.org/10.5194/acp-7-5501-2007, 2007.

Deardorff, J. W.: Parameterization of the planetary boundary layer for use in general circulation models, Mon. Weather Rev., 100, 93-106, 1972.

Ding, A. J., Fu, C. B., Yang, X. Q., Sun, J. N., Petäjä, T., Kerminen, V.-M., Wang, T., Xie, Y., Herrmann, E., Zheng, L. F., Nie, W., Liu, Q., Wei, X. L., and Kulmala, M.: Intense atmospheric pollution modifies weather: a case of mixed biomass burning with fossil fuel combustion pollution in eastern China, Atmos. Chem. Phys., 13, 10545-10554, https://doi.org/10.5194/acp-13-10545-2013, 2013.

Dubovik, O., Smirnov, A., Holben, B. N., King, M. D., Kaufman, Y. J., Eck, T. F., and Slutsker, I.: Accuracy assessments of aerosol optical properties retrieved from Aerosol Robotic Network (AERONET) Sun and sky radiance measurements, J. Geophys. Res.-Atmos., 105, 9791-9806, 2000.

Dubovik, O., Holben, B., Eck, T. F., Smirnov, A., Kaufman, Y. J., King, M. D., Tanré, D., and Slutsker, I.: Variability of absorption and optical properties of key aerosol types observed in worldwide locations, J. Atmos. Sci., 59, 590-608, 2002.

Eck, T. F., Holben, B. N., Sinyuk, A., Pinker, R. T., Goloub, P., Chen, H., Chatenet, B., Li, Z., Singh, R. P., and Tripathi, S. N.: Climatological aspects of the optical properties of fine/coarse mode aerosol mixtures, J. Geophys. Res.-Atmos., 115, 19205, https://doi.org/10.1029/2010JD014002, 2010.

Eck, T. F., Holben, B. N., Reid, J., Giles, D., Rivas, M., Singh, R. P., Tripathi, S., Bruegge, C., Platnick, S., and Arnold, G.: Fogand cloud-induced aerosol modification observed by the Aerosol Robotic Network (AERONET), J. Geophys. Res.-Atmos., 117, D07206, https://doi.org/10.1029/2011JD016839, 2012.

Fernald, F. G.: Analysis of atmospheric lidar observations: some comments, Appl. Optics, 23, 652-653, 1984.

Fu, X., Wang, S. X., Cheng, Z., Xing, J., Zhao, B., Wang, J. D., and Hao, J. M.: Source, transport and impacts of a heavy dust event in the Yangtze River Delta, China, in 2011, Atmos. Chem. Phys., 14, 1239-1254, https://doi.org/10.5194/acp14-1239-2014, 2014.

Gao, Y., Zhang, M., Liu, Z., Wang, L., Wang, P., Xia, X., Tao, M., and Zhu, L.: Modeling the feedback between aerosol and meteorological variables in the atmospheric boundary layer during a severe fog-haze event over the North China Plain, Atmos. Chem. Phys., 15, 4279-4295, https://doi.org/10.5194/acp15-4279-2015, 2015.

Gong, S., Zhang, X., Zhao, T., McKendry, I., Jaffe, D., and Lu, N.: Characterization of soil dust aerosol in China and its transport and distribution during 2001 ACE-Asia: 2. Model simulation and validation, J. Geophys. Res., 108, 4262, https://doi.org/10.1029/2002JD002633, 2003.

Hansen, J., Sato, M., and Ruedy, R.: Radiative forcing and climate response, J. Geophys. Res., 102, 6831-6864, 1997.

He, Q., Li, C., Geng, F., Yang, H., Li, P., Li, T., Liu, D., and Pei, Z.: Aerosol optical properties retrieved from Sun photometer measurements over Shanghai, China, J. Geophys. Res.-Atmos., 117, 81-81, 2012.

Holben, B. N., Eck, T. F., Slutsker, I., Tanrè, D., Buis, J. P., Setzer, A., Vermote, E., Reagan, J. A., Kaufman, Y. J., and Nakajima, T.: AERONET - a federated instrument network and data archive for aerosol characterization, Remote Sens. Environ., 66, 1-16, 1998.

Holben, B. N., Tanré, D., Smirnov, A., Eck, T. F., Slutsker, I., Abuhassan, N., Newcomb, W. W., Schafer, J. S., Chatenet, B., and Lavenu, F.: An emerging ground-based aerosol climatology: aerosol optical depth from AERONET, J. Geophys. Res.-Atmos., 106, 12067-12097, 2001.

Hsu, Y. K., Holsen, T. M., and Hopke, P. K.: Comparison of hybrid receptor models to locate PCB sources in Chicago, Atmos. Environ., 37, 545-562, 2003.

Huang, X. X., Wang, T. J., Jiang, F., Liao, J. B., Cai, Y. F., Yin, C. Q., Zhu, J. L., and Han, Y.: Studies on a severe dust storm in East Asia and its impact on the air quality of Nanjing, China, Aerosol Air Qual. Res., 13, 179-193, 2013.

IPCC: IPCC Fourth Assessment Report: climate change 2007, Cambridge University Press, Cambridge, UK and New York, NY, USA, 1340-1356, 2007.

Jacob, D. J. and Winner, D. A.: Effect of climate change on air quality, Atmos. Environ., 43, 51-63, 2009.

Jacobson, M. Z.: A physically-based treatment of elemental carbon optics: implications for global direct forcing of aerosols, Geophys. Res. Lett., 27, 217-220, 2000.

Jacobson, M. Z.: Strong radiative heating due to the mixing state of black carbon in atmospheric aerosols, Nature, 409, 695-697, 2001.

Jing, D. and Jietai, M.: Study on the distribution and variation trends of atmospheric aerosol optical depth over the Yangtze River Delta in China, in: Nucleation and Atmospheric Aerosols, edited by: O’Dowd, C. D., and Wagner, P. E., 361-370, Springer, Dordrecht, 2007.

Kim, S. W., Yoon, S. C., Kim, J., Kang, J. Y., and Sugimoto, N.: Asian dust event observed in Seoul, Korea, during 29-31 May 2008: analysis of transport and vertical distribution of dust particles from lidar and surface measurements, Sci. Total Environ., 408, 1707-1718, 2010.

Ku, J. Y., Hogrefe, C., Sistla, G., Chaw, S., Charles, L., and Gross, B.: Use of lidar backscatter to determine the PBL heights in New York City, NY, Models-3 Users' Workshop, 16-18 October 2006, Chapel Hill, NC, USA, 2006.

Leng, C., Duan, J., Xu, C., Zhang, H., Wang, Y., Wang, Y., Li, X., Kong, L., Tao, J., Zhang, R., Cheng, T., Zha, S., and Yu, X.: Insights into a historic severe haze event in Shanghai: synoptic situation, boundary layer and pollutants, Atmos. Chem. Phys., 16, 9221-9234, https://doi.org/10.5194/acp-16-9221-2016, 2016.

Levy, R. C., Remer, L. A., and Dubovik, O.: Global aerosol optical properties and application to Moderate Resolution Imaging Spectroradiometer aerosol retrieval over land, J. Geophys. Res., 112, D13210, https://doi.org/10.1029/2006JD007815, 2007a. 
Levy, R. C., Remer, L. A., Mattoo, S., Vermote, E. F., and Kaufman, Y. J.: Second-generation operational algorithm: retrieval of aerosol properties over land from inversion of Moderate Resolution Imaging Spectroradiometer spectral reflectance, J. Geophys. Res.-Atmos., 112, 319-321, 2007b.

Lewis, J. R., Welton, E. J., Molod, A. M., and Joseph, E.: Improved boundary layer depth retrievals from MPLNET, J. Geophys. Res.-Atmos., 118, 9870-9879, 2013.

Li, L., Huang, C., Huang, H. Y., Wang, Y. J., Yan, R. S., Zhang, G. F., Zhou, M., Lou, S. R., Tao, S. K., and Wang, H. L.: An integrated process rate analysis of a regional fine particulate matter episode over Yangtze River Delta in 2010, Atmos. Environ., 91, 60-70, 2014.

Li, L., An, J. Y., Zhou, M., Yan, R. S., Huang, C., Lu, Q., Lin, L., Wang, Y. J., Tao, S. K., and Qiao, L. P.: Source apportionment of fine particles and its chemical components over the Yangtze River Delta, China during a heavy haze pollution episode, Atmos. Environ., 123, 415-429, 2015.

Li, R.: Multi-satellite observation of an intense dust event over southwestern China, Aerosol Air Qual. Res., 15, 263-270, 2015.

Li, Z., Xia, X., Cribb, M., Mi, W., Holben, B., Wang, P., Chen, H., Tsay, S. C., Eck, T. F., and Zhao, F.: Aerosol optical properties and their radiative effects in northern China, J. Geophys. Res.Atmos., 112, 321-341, 2007.

Li, Z., Lau, W. K. M., Ramanathan, V., Wu, G., Ding, Y., Manoj, M. G., Liu, J., Qian, Y., Li, J., and Zhou, T.: Aerosol and monsoon climate interactions over Asia, Rev. Geophys., 54, 866-929, 2016.

Liu, G., Li, J., Wu, D., and Xu, H.: Chemical composition and source apportionment of the ambient $\mathrm{PM}_{2.5}$ in Hangzhou, China, Particuology, 18, 135-143, 2015.

Liu, J., Zheng, Y., Li, Z., Flynn, C., Welton, E. J., and Cribb, M.: Transport, vertical structure and radiative properties of dust events in southeast China determined from ground and space sensors, Atmos. Environ., 45, 6469-6480, 2011.

Liu, Q., He, Q., Fang, S., Ying, G., Ma, C., Chen, Y., Kang, Y., $\mathrm{Hu}, \mathrm{P}$., Hua, Z., and Yao, Y.: Vertical distribution of ambient aerosol extinctive properties during haze and haze-free periods based on the Micro-Pulse Lidar observation in Shanghai, Sci. Total Environ., 574, 1502-1511, 2016.

Liu, S. Y. and Liang, X. Z.: Observed diurnal cycle climatology of planetary boundary layer height, J. Climate, 23, 5790-5809, 2010.

Martins, J. V., Artaxo, P., Liousse, C., Reid, J. S., Hobbs, P. V., and Kaufman, Y. J.: Effects of black carbon content, particle size, and mixing on light absorption by aerosols from biomass burning in Brazil, J. Geophys. Res.-Atmos., 103, 32041-32050, 1998.

Medeiros, B., Hall, A., and Stevens, B.: What controls the mean depth of the PBL?, J. Climate, 18, 3157-3172, 2005.

Ming, L., Jin, L., Li, J., Fu, P., Yang, W., Liu, D., Zhang, G., Wang, Z., and Li, X.: $\mathrm{PM}_{2.5}$ in the Yangtze River Delta, China: chemical compositions, seasonal variations, and regional pollution events, Environ. Pollut., 223, 200-212, 2017.

Ngan, F., Stein, A., and Draxler, R.: Inline coupling of WRFHYSPLIT: model development and evaluation using tracer experiments, J. Appl. Meteorol. Clim., 54, 1162-1176, 2015.

Omar, A. H., Winker, D. M., Vaughan, M. A., Hu, Y., Trepte, C. R., Ferrare, R. A., Lee, K.-P., Hostetler, C. A., Kittaka, C., and Rogers, R. R.: The CALIPSO automated aerosol classification and lidar ratio selection algorithm, J. Atmos. Ocean. Tech., 26, 1994-2014, 2009.

Pan, L., Che, H., Geng, F., Xia, X., Wang, Y., Zhu, C., Chen, M., Gao, W., and Guo, J.: Aerosol optical properties based on ground measurements over the Chinese Yangtze Delta Region, Atmos. Environ., 44, 2587-2596, 2010.

Petäjä, T., Järvi, L., Kerminen, V. M., Ding, A. J., Sun, J. N., Nie, W., Kujansuu, J., Virkkula, A., Yang, X., and $\mathrm{Fu}$, C. B.: Enhanced air pollution via aerosol-boundary layer feedback in China, Sci. Rep.-UK, 6, 18998, https://doi.org/10.1038/srep18998, 2016.

Pilat, M. J. and Charlson, R. J.: Theoretical and optical studies of humidity effects on the size distribution of a hygroscopic aerosol, J. Rech. Atmos., 2, 166-170, 1966.

Polissar, A. V., Hopke, P. K., Paatero, P., Kaufmann, Y. J., Hall, D. K., Bodhaine, B. A., Dutton, E. G., and Harris, J. M.: The aerosol at Barrow, Alaska: long-term trends and source locations, Atmos. Environ., 33, 2441-2458, 1999.

Qi, B.: Seasonal variation of aerosol optical properties in an urban site of the Yangtze Delta region of China, Aerosol Air Qual. Res., 16, 2884-2896, 2016.

Sakai, T., Shibata, T., Iwasaka, Y., Nagai, T., Nakazato, M., Matsumura, T., Ichiki, A., Kim, Y. S., Tamura, K., and Troshkin, D.: Case study of Raman lidar measurements of Asian dust events in 2000 and 2001 at Nagoya and Tsukuba, Japan, Atmos. Environ., 36, 5479-5489, 2002.

Sakai, T., Nagai, T., Nakazato, M., Mano, Y., and Matsumura, T.: Ice clouds and Asian dust studied with lidar measurements of particle extinction-to-backscatter ratio, particle depolarization, and water-vapor mixing ratio over Tsukuba, Appl. Optics, 42, 7103-7116, 2003.

Seibert, P., Kromp-Kolb, H., Baltensperger, U., Jost, D. T., and Schwikowski, M.: Trajectory analysis of high-alpine air pollution data, Springer US, Boston, MA, USA, 253-269, 1994.

Sirois, A. and Bottenheim, J. W.: Use of backward trajectories to interpret the 5 year record of PAN and $\mathrm{O}_{3}$ ambient air concentrations at Kejimkujik National Park, Nova Scotia, J. Geophys. Res.-Atmos., 100, 2867-2882, 1995.

Stocker, T. F., Qin, D., Plattner, G.-K., Tignor, M., Allen, S. K., Boschung, J., Nauels, A., Xia, Y., Bex, B., and Midgley, B.: IPCC, 2013: Climate Change 2013: The Physical Science Basis. Contribution of Working Group I to the Fifth Assessment Report of the Intergovernmental Panel on Climate Change, Cambridge University Press, Cambridge, UK and New York, NY, USA, 2013.

Sun, T., Che, H., Wu, J., Wang, H., Wang, Y., and Zhang, X.: The variation in visibility and its relationship with surface wind speed in China from 1960 to 2009, Theor. Appl. Climatol., 131, 335347, https://doi.org/10.1007/s00704-016-1972-x, 2018.

Tang, G., Zhang, J., Zhu, X., Song, T., Münkel, C., Hu, B., Schäfer, K., Liu, Z., Zhang, J., Wang, L., Xin, J., Suppan, P., and Wang, Y.: Mixing layer height and its implications for air pollution over Beijing, China, Atmos. Chem. Phys., 16, 2459-2475, https://doi.org/10.5194/acp-16-2459-2016, 2016.

Tao, M., Chen, L., Su, L., and Tao, J.: Satellite observation of regional haze pollution over the North China Plain, J. Geophys. Res.-Atmos., 117, 12203, https://doi.org/10.1029/2012JD017915, 2012. 
Tao, M., Chen, L., Wang, Z., Ma, P., Tao, J., and Jia, S.: A study of urban pollution and haze clouds over northern China during the dusty season based on satellite and surface observations, Atmos. Environ., 82, 183-192, 2014.

Tao, M., Chen, L., Li, R., Wang, L., Wang, J., Wang, Z., Tang, G., and Tao, J.: Spatial oscillation of the particle pollution in eastern China during winter: implications for regional air quality and climate, Atmos. Environ., 144, 100-110, 2016.

Uno, I., Eguchi, K., Yumimoto, K., Takemura, T., Shimizu, A., Uematsu, M., Liu, Z., Wang, Z., Hara, Y., and Sugimoto, N.: Asian dust transported one full circuit around the globe, Nat. Geosci., 2, 557-560, 2009.

Vaughan, M., Young, S., Winker, D., Powell, K., Omar, A., Liu, Z., Hu, Y., and Hostetler, C.: Fully automated analysis of space-based lidar data: an overview of the CALIPSO retrieval algorithms and data products, Proc. SPIE, 17, 5575, https://doi.org/10.1117/12.572024, 2004.

Wang, S. X. and Zhang, C. Y.: Spatial and temporal distribution of air pollutant emissions from open burning of crop residues in China, Sciencepaper online, 3, 329-333, 2008.

Wang, Y., Zhuang, G., Zhang, X., Huang, K., Xu, C., Tang, A., Chen, J., and An, Z.: The ion chemistry, seasonal cycle, and sources of $\mathrm{PM}_{2.5}$ and TSP aerosol in Shanghai, Atmos. Environ., 40, 2935-2952, 2006a.

Wang, Y. Q., Zhang, X. Y., and Arimoto, R.: The contribution from distant dust sources to the atmospheric particulate matter loadings at XiAn, China during spring, Sci. Total Environ., 368, 875$883,2006 \mathrm{~b}$.

Winker, D. M., Vaughan, M. A., Omar, A., Hu, Y., Powell, K. A., Liu, Z., Hunt, W. H., and Young, S. A.: Overview of the CALIPSO mission and CALIOP data processing algorithms, J. Atmos. Ocean. Tech., 26, 2310-2323, 2009.

Wu, J., Fu, C., Zhang, L., and Tang, J.: Trends of visibility on sunny days in China in the recent 50 years, Atmos. Environ., 55, 339346, 2012.

Wu, Y., Han, Y., Voulgarakis, A., Wang, T., Li, M., Wang, Y., Xie, M., Zhuang, B., and Li, S.: An agricultural biomass burning episode in eastern China: transport, optical properties, and impacts on regional air quality, J. Geophys. Res.-Atmos., 122, 2304-2324, 2017.

Xia, X., Li, Z., Holben, B., Wang, P., Eck, T., Chen, H., Cribb, M., and Zhao, Y.: Aerosol optical properties and radiative effects in the Yangtze Delta region of China, J. Geophys. Res.-Atmos., 112, 449-456, 2007.

Xia, X., Chen, H., Goloub, P., Zong, X., Zhang, W., and Wang, P.: Climatological aspects of aerosol optical properties in North China Plain based on ground and satellite remote-sensing data, J. Quant. Spectrosc. Ra., 127, 12-23, 2013

Xiao, Z.-M., Zhang, Y.-F., Hong, S.-M., Bi, X.-H., Jiao, L., Feng, Y.-C., and Wang, Y.-Q.: Estimation of the main factors influencing haze, based on a long-term monitoring campaign in Hangzhou, China, Aerosol Air Qual. Res., 11, 873-882, 2011.

Xin, J., Du, W., Wang, Y., Gao, Q., Li, Z., and Wang, M.: Aerosol optical properties affected by a strong dust storm over central and northern China, Adv. Atmos. Sci., 27, 562-574, https://doi.org/10.1007/s00376-009-9023-5, 2010.

Xin, Y.: Identification of long-range transport pathways and potential sources of $\mathrm{PM}_{10}$ in Tibetan Plateau uplift area: case study of
Xining, China in 2014, Aerosol Air Qual. Res., 16, 1044-1054, 2016.

Xing, C., Liu, C., Wang, S., Chan, K. L., Gao, Y., Huang, X., Su, W., Zhang, C., Dong, Y., Fan, G., Zhang, T., Chen, Z., Hu, Q., Su, H., Xie, Z., and Liu, J.: Observations of the vertical distributions of summertime atmospheric pollutants and the corresponding ozone production in Shanghai, China, Atmos. Chem. Phys., 17, 1427514289, https://doi.org/10.5194/acp-17-14275-2017, 2017.

Yong, H., Wu, Y., Wang, T., Xie, C., Zhao, K., Zhuang, B., and Li, S.: Characterizing a persistent Asian dust transport event: optical properties and impact on air quality through the groundbased and satellite measurements over Nanjing, China, Atmos. Environ., 115, 304-316, 2015.

Zhang, J. and Li, X.: Vertical distribution of sand-dust aerosols and the relationships with atmospheric environment, J. Arid Land, 4, 357-368, 2012.

Zhang, J., Wang, L., Chen, J., Feng, S., Shen, J., and Jiao, L.: Hygroscopicity of ambient submicron particles in urban Hangzhou, China, Front. Env. Sci. Eng., 5, 342-347, 2011.

Zhang, R., Jing, J., Tao, J., Hsu, S.-C., Wang, G., Cao, J., Lee, C. S. L., Zhu, L., Chen, Z., Zhao, Y., and Shen, Z.: Chemical characterization and source apportionment of $\mathrm{PM}_{2.5}$ in Beijing: seasonal perspective, Atmos. Chem. Phys., 13, 7053-7074, https://doi.org/10.5194/acp-13-7053-2013, 2013.

Zhang, X. Y., Arimoto, R., Zhu, G. H., Chen, T., and Zhang, G. Y.: Concentration, size-distribution and deposition of mineral aerosol over Chinese desert regions, Tellus B, 50, 317-330, 1998.

Zhang, X. Y., Wang, Y. Q., Niu, T., Zhang, X. C., Gong, S. L., Zhang, Y. M., and Sun, J. Y.: Corrigendum to "Atmospheric aerosol compositions in China: spatial/temporal variability, chemical signature, regional haze distribution and comparisons with global aerosols' published in Atmos. Chem. Phys., 12, 779-799, 2012, Atmos. Chem. Phys., 12, 6273-6273, https://doi.org/10.5194/acp-12-6273-2012, 2012.

Zhang, Z., Zhou, W., Wenig, M., and Yang, L.: Impact of longrange desert dust transport on coastal East Asia: analysis of urban dust concentration and wet deposition with model simulation, Air Qual. Atmos. Hlth., 1-13, 2016.

Zhu, J., Che, H., Xia, X., Chen, H., Goloub, P., and Zhang, W.: Column-integrated aerosol optical and physical properties at a regional background atmosphere in North China Plain, Atmos. Environ., 84, 54-64, 2014.

Zhuang, B. L., Wang, T. J., Liu, J., Ma, Y., Yin, C. Q., Li, S., Xie, M., Han, Y., Zhu, J. L., Yang, X. Q., and Fu, C. B.: Absorption coefficient of urban aerosol in Nanjing, west Yangtze River Delta, China, Atmos. Chem. Phys., 15, 13633-13646, https://doi.org/10.5194/acp-15-13633-2015, 2015. 